\title{
Microbial Safety of Milk Production and Fermented Dairy Products in Africa
}

\author{
James Owusu-Kwarteng ${ }^{1, *(\mathbb{D})}$, Fortune Akabanda ${ }^{2}$, Dominic Agyei ${ }^{3} \mathbb{D}$ and Lene Jespersen ${ }^{4}$ \\ 1 Department of Food Science and Technology, University of Energy and Natural Resources, \\ BS-0061-2164 Sunyani, Ghana \\ 2 Department of Applied Biology, University for Development Studies, P.O. Box 24, NT-0272-1946 Tamale, \\ Ghana; fakabanda@gmail.com \\ 3 Department of Food Science, University of Otago, Dunedin 9054, New Zealand; Dominic.Agyei@otago.ac.nz \\ 4 Department of Food Science, Food Microbiology, University of Copenhagen, Rolighedsvej 26, \\ DK 1958 Frederiksberg Copenhagen, Denmark; lj@food.ku.dk \\ * Correspondence: james.owusu-kwarteng@uenr.edu.gh; Tel.: +233-209-265-738
}

Received: 22 April 2020; Accepted: 5 May 2020; Published: 17 May 2020

\begin{abstract}
In Africa, milk production, processing and consumption are integral part of traditional food supply, with dairy products being a staple component of recommended healthy diets. This review provides an overview of the microbial safety characteristics of milk production and fermented dairy products in Africa. The object is to highlight the main microbial food safety hazards in the dairy chain and to propose appropriate preventive and control measures. Pathogens of public health concern including Mycobacterium bovis, Brucella abortus and Coxiella burnettii, which have largely been eradicated in many developed nations, still persist in the dairy chain in Africa. Factors such as the natural antimicrobial systems in milk and traditional processing technologies, including fermentation, heating and use of antimicrobial additives, that can potentially contribute to microbial safety of milk and dairy products in Africa will be discussed. Practical approaches to controlling safety hazards in the dairy chain in Africa have been proposed. Governmental regulatory bodies need to set the necessary national and regional safety standards, perform inspections and put measures in place to ensure that the standards are met, including strong enforcement programs within smallholder dairy chains. Dairy chain actors would require upgraded knowledge and training in preventive approaches such as good agricultural practices (GAP), hazard analysis and critical control points (HACCP) design and implementation and good hygienic practices (GHPs). Food safety education programs should be incorporated into school curricula, beginning at the basic school levels, to improve food safety cognition among students and promote life-long safe food handling behaviour.
\end{abstract}

Keywords: pathogens; pasteurization; raw milk; fermentation; microbial hazards; HACCP; dairy

\section{Introduction}

Historically, milk and dairy products have been significant components in the diets of Africans and continue to play an important and increasing role in the diets of the growing population of both rural and urban communities [1-3]. Generally, milk and dairy products are rich in nutrients, delivering high quality proteins, micronutrients, vitamins and energy-containing fats [4,5]. Milk, thus, provides an ideal environment for the growth of wide variety of food-borne microorganisms and zoonotic agents [6]. The microbiological quality of milk, at the point of milking from a healthy animal, is theoretically expected to be safe for human consumption. However, once it is secreted from the udder, milk can easily be contaminated by spoilage microorganisms and food-borne pathogens from various sources including animal faeces, soil, air, feed, water, equipment, animal hides and people. Thus, the prevalence of pathogenic and spoilage microorganisms in milk and dairy products is influenced by a high number of 
factors and their combinations. These factors may include health status of the dairy herd, hygiene level in the dairy farm environment, milking and prestorage conditions, available storage facilities and technologies, farm management practices, geographic location and season [7,8]. In addition to microbial hazards, milk and dairy products can also contain chemical hazards and contaminants mainly introduced through the environment, animal feedstuffs, animal husbandry and industry practices. Thus, safety and production are intrinsically linked in the dairy food chain; from production through handling and processing to consumption. Therefore, in order to minimize the food safety risks associated with milk and dairy products, there is the need for a continuous system of preventive measures beginning with safety of animal feed, through good farming practices and on-farm controls, to good manufacturing and hygiene practices, consumers safety awareness, and proper application of food safety management systems throughout the dairy chain [9].

Food-safety risks associated with raw milk and dairy products consumption vary considerably between developed and developing countries. While the dairy sector in developed nations is largely industrialized, characterized by routine application of pasteurization technologies, the dairy sector in developing countries is dominated by many smallholder dairy farmers and processors [9]. In most countries in Africa, the informal sector which handles most of the milk and dairy products is characterized by unpasteurized milk sold through small-scale channels that lack a cold chain and has little or no regulatory control $[10,11]$. This review, therefore, provides a comprehensive overview of the microbial food safety issues associated with raw milk production and traditional dairy products in Africa. Additionally, the paper discusses the contribution of factors such as natural antimicrobials components in milk and traditional milk processing methods to the safety of raw milk and dairy products in Africa. Finally, practical steps aimed at ensuring safety in the African dairy chain are proposed.

\section{Food Safety Hazards in the Dairy Chain}

Food-safety hazard generally refers to any biological, chemical or physical agent in a food, or condition of food with the potential to cause adverse health consequences for consumers [12]. Such hazards may be introduced into the dairy chain at any time during primary production, milking, formulation and processing, packaging and labelling, transportation, storage, preparation, and serving. Major food safety hazards associated with raw milk production and dairy products may be put into three categories: biological, chemical and physical, as shown in Table 1 [13]. From raw milk production through processing to the consumer, milk is exposed to several hazards, which ultimately influence the safety and quality of the final product. Some of these hazards may stem from animal husbandry practices, through their feeding, milking and processing.

Table 1. Main categories of food safety hazards associated with milk and dairy products (adopted from the Food and Agricultural Organization (FAO), [13]).

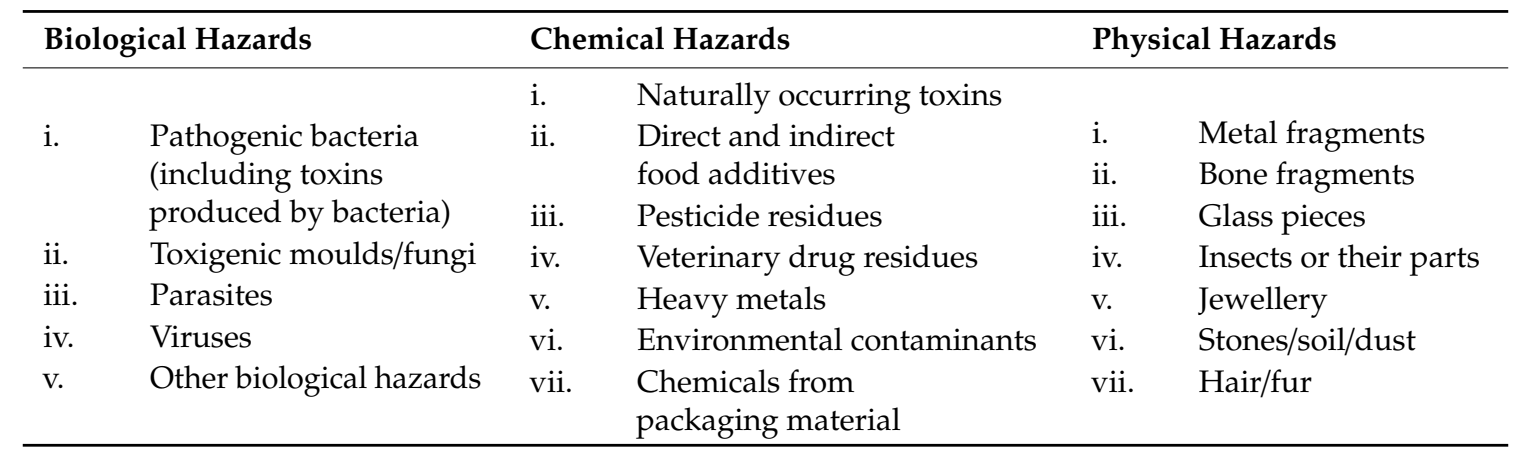

Generally, the traditional production of raw milk and dairy products in Africa follows few common stages beginning with animal feed supply, followed by the production of raw milk which may be sold directly to consumers without processing, or further processed into various traditional products by small scale processors. Typically, along the dairy chain in Africa, milk may be consumed 
as nonpasteurized milk, heated milk or processed into various fermented yoghurt-like and cheese-like products, as shown in Figure 1.

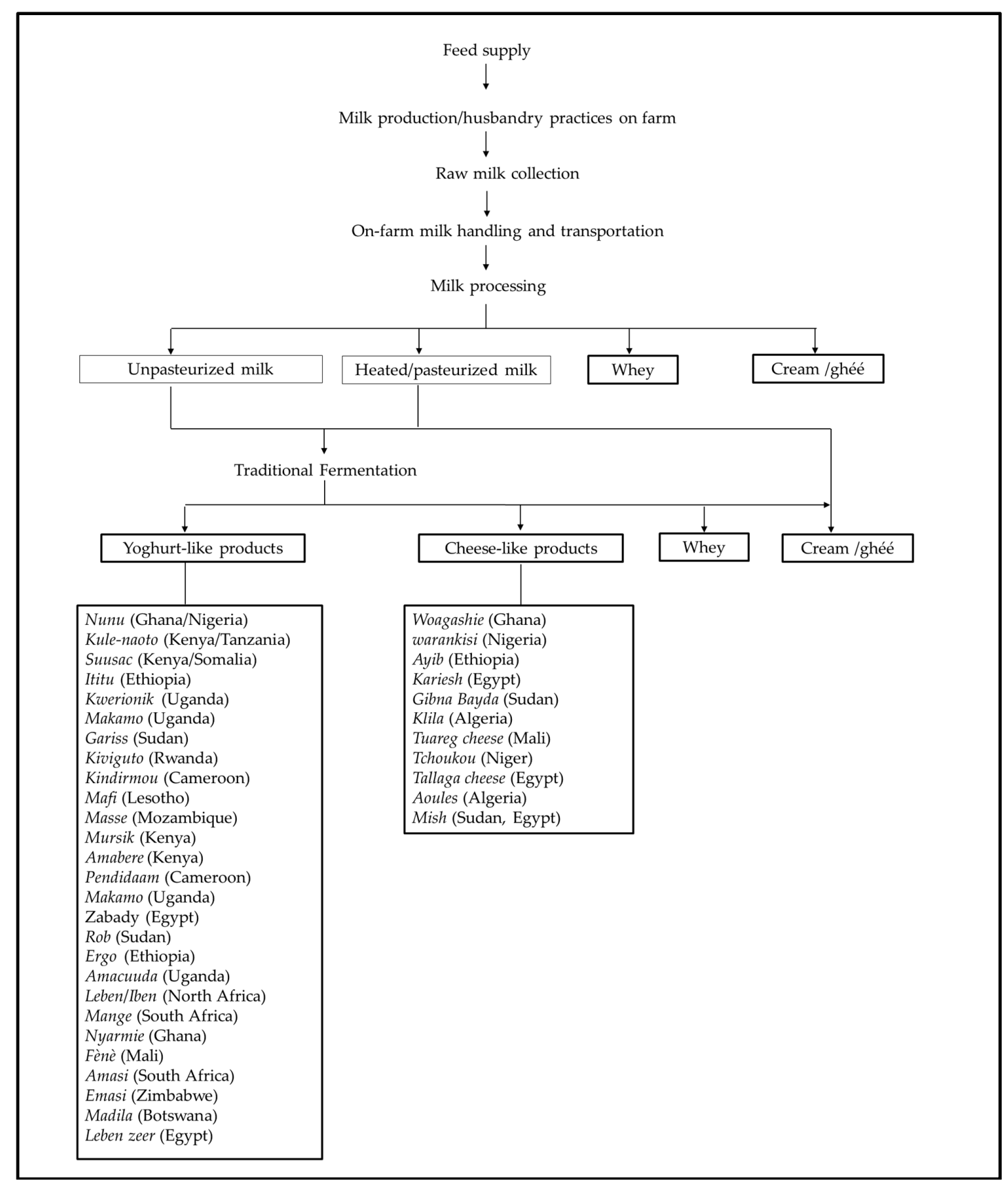

Figure 1. Overview of various stages involved in common African traditional dairy chains.

\section{Risk Factors for Microbiological Hazards in Dairy Production and Processing in Africa}

From a healthy animal, raw milk is expected to harbour no pathogens at the point of collection. However, this is seldom the case. Generally, pathogenic microorganisms can contaminate raw milk in two ways. First, endogenous contamination occurs when milk is contaminated by a direct transfer of pathogens from the blood (systemic infection) of an infected animal into the milk, or via an infection in the udder. The second means by which fresh milk can be contaminated, known as exogenous contamination, occurs where milk is contaminated during or after collection by animal faeces, the exterior of the udder and teats, the skin, and other environmental sources [14]. Table 2 summarizes important risk factors and their implications for milk safety. 
Table 2. Major microbiological risk factors and their implications for safety in the dairy chain in Africa.

\begin{tabular}{|c|c|c|}
\hline Step in Dairy Chain & Important Risk Factors & Implications for Milk Safety \\
\hline Primary production & $\begin{array}{ll}- & \text { Diseases (mastitis) } \\
\text { - } & \text { Housing, bedding and husbandry } \\
\text { - } & \text { Feed and water quality } \\
\text { - } & \text { Waste management }\end{array}$ & $\begin{array}{l}\text { - Increased shedding of pathogens directly into milk from diseased animals } \\
\text { (including asymptomatic carriers). } \\
\text { Poor housing and husbandry practices increase the risk of udder } \\
\text { contamination due to high stocking, concentration of waste, stress and soiled } \\
\text { bedding, leading to contamination of milking environment and raw milk. } \\
\text { - Increased risk of milk contamination can result from using poor quality water } \\
\text { for stock drinking, teat washing and cleaning. } \\
\text { - Contaminated or poorly prepared feed may increase faecal shedding of } \\
\text { pathogens into milk and milking environment. }\end{array}$ \\
\hline Milk collection & $\begin{array}{ll}- & \text { Milking practices } \\
- & \text { Equipment cleaning } \\
- & \text { Personnel hygiene }\end{array}$ & $\begin{array}{l}\text { Poor milking practices, including dirty, chapped or cracked teats, insufficient } \\
\text { cleaning and maintenance of milking equipment, and poor personnel hygiene } \\
\text { can lead to direct contamination of raw milk with pathogens. }\end{array}$ \\
\hline Raw milk storage & $\begin{array}{l}\text { Availability and efficiency of cold } \\
\text { storage facilities }\end{array}$ & $\begin{array}{l}\text { Inappropriate temperature control of raw milk, coupled with the usually high } \\
\text { temperature in the region and erratic power supply, can lead to accelerated } \\
\text { growth of pathogens in milk during storage. }\end{array}$ \\
\hline Packaging & - $\quad$ Packaging Equipment and material & $\begin{array}{l}\text { Poor packaging, inappropriate packaging materials and poor hygiene can } \\
\text { contribute to cross contamination of milk or open up milk to contamination } \\
\text { from the environment. }\end{array}$ \\
\hline Transportation and distribution & $\begin{array}{l}\text { - Transportation mode } \\
\text { - } \quad \text { Road network between milk collection } \\
\text { centres and market centres } \\
\text { - Maintenance of cold chain }\end{array}$ & $\begin{array}{l}\text { - Transporting of raw milk between farms and market centres by foot, bicycles, } \\
\text { motorbikes or other means without a proper cold chain enables growth } \\
\text { of pathogens. } \\
\text { Poor road network systems increase the time for transportation and } \\
\text { distribution of raw milk, and coupled with poor cold chain facilities, allows } \\
\text { the rapid growth of pathogens in raw milk. }\end{array}$ \\
\hline
\end{tabular}


Table 2. Cont

\begin{tabular}{|c|c|c|}
\hline Step in Dairy Chain & Important Risk Factors & Implications for Milk Safety \\
\hline Traditional milk processing & $\begin{array}{l}\text { - } \quad \text { Pasteurization/thermal treatment } \\
\text { - } \quad \text { Permentation practices } \\
\text { processing environment. }\end{array}$ & $\begin{array}{l}\text { - Inadequate pasteurization temperatures may not be able to eliminate } \\
\text { pathogens in already contaminated milk, and may even encourage the faster } \\
\text { growth of pathogens. } \\
\text { Spontaneous fermentations (without properly defined starter cultures), } \\
\text { coupled with poor time/temperature controls can expose fermented products } \\
\text { to pathogenic microorganisms. } \\
\text { - Poor sanitation of processing environments and personal hygiene by milk } \\
\text { processors can lead to a direct contamination of processed milk products with } \\
\text { pathogenic microorganisms. }\end{array}$ \\
\hline Consumer practices & $\begin{array}{l}\text { - } \\
\text { - } \quad \text { Adherage temperature at home storage } \\
\text { good personal hygiene }\end{array}$ & $\begin{array}{l}\text { - Poor refrigeration during home storage of both raw and processed milk can } \\
\text { accelerate the proliferation of pathogenic microorganisms. } \\
\text { Lack of proper hygiene and nonadherence to handling instructions can lead to } \\
\text { contamination and proliferation of pathogenic microorganisms. }\end{array}$ \\
\hline
\end{tabular}


During the primary production stage, pathogens can contaminate milk through various routes. Animal feed and drinking water often serve as sources of microbial contamination. Predominant among the dairy production systems in Africa are the rural smallholder dairies in which farm animals are fed on grass, crop residues and cultivated fodder, or they roam the land in search of grazing grounds and water. Consequently, the microbiological quality of feed and water for dairy animals are not routinely assessed under these systems, and therefore there is a high risk for the ingestion of contaminated feed and water by dairy animals in Africa. Upon ingestion of contaminated water or feed, surviving (spore-formers) pathogens can be expelled into the farm environment and subsequently attach to teats and udder of dairy animals. Apart from contaminating the external surfaces of udder and teats, several potential pathogens including the genera Staphylococcus, Streptococcus, Bacillus, Micrococcus, and Corynebacterium can colonize the mammary glands of dairy animals even without any disease symptoms [15].

Mastitis, an inflammation of the mammary glands and udder tissues, is caused by a large variety of common bacteria, fungi, mycoplasmas and algae [16] infecting the mammary glands of dairy animals. Mastitis adversely affects animal health, milk quality, consumer safety, and can lead to great economic losses for milk production [17-19]. In sub-Sahara Africa, both subclinical mastitis (SCM) and clinical mastitis (CM) among dairy cows have been reported with prevalence rates in the range of $16.1 \%-90.3 \%$ and $4.8 \%-25.5 \%$, respectively [20-22]. A recent report indicates that the prevalence of subclinical mastitis among dairy cows in some districts in Rwanda is $50.4 \%$ and the milk collected from positive mastitis cows were found to harbour coagulase negative Staphylococci (51.5\%), Staphylococcus aureus (20.6\%), Streptococcus species (10.3\%), Bacillus species (10.3\%), Streptococcus agalactiae (5.8\%), and Escherichia coli (1.5\%) [23]. Mastitis among dairy herds is a major constraint, and the disease has been identified as a primary cause of poor-quality and compromises the safety of raw milk in Ethiopia [24]. Generally, milk can easily become contaminated before it is secreted from the udder owing to mastitis. Although microbial contamination of milk during milking is difficult to completely avoid [25], it is of utmost importance to maintain a very high level of hygiene in dairy farming practices and proper cleaning of teats during milking for good udder health and optimum milk quality, and to ensure safety [26,27].

Once milk is secreted from the udder, it can be contaminated from several sources including air, faeces, bedding material, soil, feed, water, equipment, animal hides and people. A critical factor affecting milk safety is milking hygiene. Adequate milking hygiene potentially reduces the contaminating microorganisms and prevents them from inhabiting the immediate environment or skin of the animals, hands personnel and milking equipment, thereby minimizing their spread during milking [28]. High prevalence of pathogens in raw milk and occurrence of mastitis have previously been recorded in farms that practiced poor milking hygiene in Africa [22,29-31]. The dairy farm environment can be a reservoir of foodborne pathogens and serve as a major source of microbial contamination of raw milk due to direct contact with the milk. The use unsterilized collection vessels (containers) and other practices such as milking with unsanitized bare hands and allowing calves to feed without cleaning the teats of udders, expose milk to microbial contamination. In most small-scale milk production farms in Africa, there are no strict implementations of procedures for cleaning and disinfection of materials used during production processes, from milking to the sales of final products. While most foodborne pathogens such as E. coli, Salmonella spp. and Campylobacter spp. inhabit the ruminant intestinal tract, others including Listeria spp. and Bacillus spp. are widespread in nature and live in soils and plant environments. Thus, these environmental microorganisms can contaminate the milk by direct contact or through milking equipment and personnel on the farm if good hygiene management practices are not followed. Additionally, intentional adulterated of raw milk with contaminated water has been reported [32], a practice that potentially serves as another major source of pathogenic microorganisms in raw milk.

Storage and transportation of raw milk immediately after milking through to point of sale or processing are critical for safety and quality. In order to prevent proliferation of pathogens that 
contaminate freshly collected milk, there should be strict time and temperature controls between the milking and the processing of dairy products. Ideally, raw milk should be immediately cooled to below $4{ }^{\circ} \mathrm{C}$ to prevent microbial growth and ensure high-quality, safe milk for processing and consumption. This is in practise not possible for most small-scale producers in Africa, and therefore pasteurisation and sterilization of the milk are strongly recommended. This is unfortunately often not the case. Modern cooling facilities including mechanical refrigeration or cooling tanks are not available to the many small-scale dairy producers for reasons such as high initial investment and running costs and technical problems, including the lack or unreliable supply of electricity. Additionally, the majority of raw milk producers in Africa are mostly located in remote rural areas with poor road networks making it difficult to transport milk to urban markets and small-scale processing units. Subsequently, raw milk is often transported from the farm to small-scale processing units in urban market centres by bicycles, motorcycles, animals (donkeys), or by foot. The usual high ambient temperatures, often reaching $35-42{ }^{\circ} \mathrm{C}$ in most parts of sub-Sahara Africa, highlight the problem by accelerating the growth of spoilage and pathogenic microorganisms during transportation of raw milk.

The majority of milk produced in Africa is processed into a variety of traditional milk products by small-scale processing units or processors. The final products including spontaneously fermented yoghurt-like milk, traditional cheeses and butter, are produced with slight variations in processing methods depending on country or local region, which is affected by local tastes, dietary habits or culinary traditions $[33,34]$. The production of African traditional dairy products is based on recipes handed down from one generation to another, and processors often do not have access to formal training but learn by seeing, hearing and practicing [34]. Small-scale processors of traditional milk products often lack pasteurization, storage and packaging facilities and do not adhere to good manufacturing and hygiene practices (GMP/GHPs), including the implementation of starter culture procedures for milk fermentation. The processing of milk into yoghurts and other fermented products in most parts of Africa relies on spontaneous fermentation or back-slopping where a part of a previous batch of a fermented product is used to inoculate the new batch [34-36]. Consequently, traditional African fermented milk products may be susceptible to contamination with human pathogens of public health concerns due to the lack of proper control measures and adherence to good manufacturing practices (GMP) in the traditional fermentation processes.

\section{Pathogens Occurring in Raw Milk and Dairy Products in Africa}

The major pathogens of concern in milk and dairy products have traditionally included Mycobacterium bovis, Brucella abortus and Coxiella burnettii, which are the causative agents of bovine tuberculosis and a form of human tuberculosis, brucellosis and $Q$ fever, respectively. Unfortunately, while these pathogens and their diseases have been reported to be largely eradicated in many developed countries, they still persist or are re-emerging in some countries in Africa [37-41]. An overview of common pathogenic microorganisms occurring in milk and dairy products in some African countries is presented in Figure 2.

Mycobacterium bovis, the causative agent for bovine tuberculosis, has been detected in milk and dairy products in different African countries including South Africa [38,42], Mozambique [43], Nigeria [44], Tunisia [45] and Zambia [46]. Thus, the consumption of unpasteurized raw milk and dairy products continue to be a major risk for exposure to M. bovis in Africa. While bovine tuberculosis is known to be widespread in Africa, the limited or lack of sufficient data to expose the true epidemiological picture and burden of the disease in many African countries is a major concern, particularly when the burden of bovine tuberculosis might be considerably underestimated in humans [47-49]. 


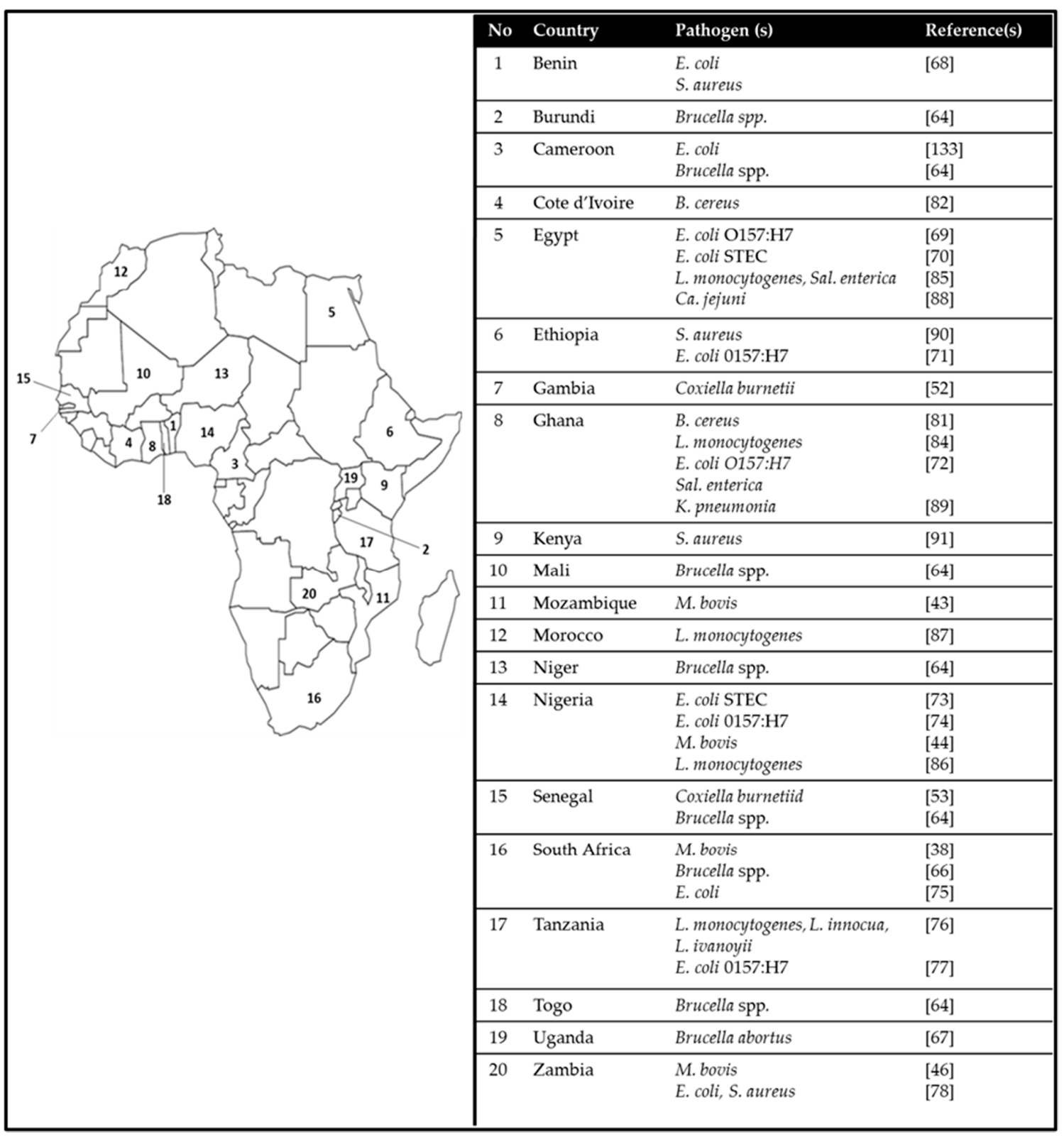

Figure 2. Pathogenic microorganisms occurring in milk and dairy products in some African countries. E.: Escherichia; S.: Staphylococcus; B.: Bacillus; L.: Listeria; Sal.: Salmonella; Ca.: Campylobacter; K.: Klebsiella; M.: Mycobacterium.

Coxiella burnetii, an obligatory intracellular Gram-negative bacterium belonging to the family of Coxiellaceae is the causative organism of $\mathrm{Q}$ fever, a zoonosis of almost worldwide distribution except in New Zealand $[40,50,51]$. The most common reservoirs for C. burnetii include cattle, sheep and goats, and are considered the main sources of human infection [50]. Thus, consumption of non-pasteurized milk and their products in Africa may be a significant source of human contamination with C. burnetii, as this pathogen has been detected in up to $63 \%$ of cattle milk samples in Nigeria [40]. Furthermore, C. burnetii has been detected in milk samples in Gambia [52] and Senegal [53]. The presence of C. burnetii in milk samples raises concern on the role of milk as a source for human infection, particularly in regions where unpasteurized milk is consumed [54]. While Q fever is usually not considered a tropical disease, C. burnetii was found as the etiological agent in 5\% of severe pneumonia cases in Tanzania [55]. Additionally, a study of a cohort of severely ill febrile patients in Tanzania revealed $26.2 \%$ zoonoses, among which 30\% were reportedly $Q$ fever [56]. Furthermore, C. burnetii accounts for about 1 to $3 \%$ 
of infective endocarditis in Tunisia and Algeria while $Q$ fever accounts for about $5 \%$ of acute febrile illnesses in Burkina Faso [40]. About 9\% of community-acquired pneumonia among patients aged above 15 years in Cameroon tested positive for C. burnetii [40], with C. burnetii being the third most frequently isolated agent of pneumonia, after Streptococcus pneumoniae and Mycoplasma pneumoniae in Cameroon [57].

Species of Brucella including Brucella abortus, B. melitensis, B. suis and B. canis are all capable of producing brucellosis in humans, with the disease being considered to represent one of the highest public health burdens of any zoonosis globally [58-60]. Ruminants are the primary hosts for B. abortus and $B$. melitensis, and humans become infected by consuming raw milk and dairy products, by direct contact with aborted foetuses, afterbirth and parturition fluids and during slaughter practices [61-63]. Although there is scanty prevalence data on brucellosis in Africa, it is suspected that the disease may be endemic in the region due to the high level of infection among dairy herds in different parts of the region [64]. Banfo et al. [65] estimated that up to $30 \%$ of milk and dairy products at selling points in Bamako, Mali were contaminated with Brucella. More recently, Brucella spp., particularly B. abortus, have been reported in milk and dairy products with high prevalence in some African countries such including South Africa [66], Uganda [67], Togo, Mali, Burundi, Cameroon, Senegal and Niger [64]. These reports indicate that brucellosis or the causative microorganisms are widespread among dairy supply chains of Africa, and this presents a serious public health threat to local populations, particularly consumers of raw milk and traditional dairy products, as well as dairy farm workers.

Other pathogens of significant safety concern in the African dairy chain are toxigenic strains of Escherichia coli, Bacillus cereus and Listeria monocytogenes. Strains of toxigenic E. coli have been reported in raw milk from different African countries such as Benin [68], Egypt [69,70], Ethiopia [71], Ghana [72], Nigeria [73,74], South Africa [75], Tanzania [76,77] and Zambia [78]. Shiga toxin producing Escherichia coli (STEC), has emerged as a group of highly pathogenic E. coli strains characterized by the production of one or more Shiga toxins. Similarly, B. cereus are of particular concern in food safety and public health due of their capacity to cause disease in humans through the production of various forms of enterotoxins and emetic toxins $[79,80]$. Strains of $B$. cereus possessing various forms of virulent factors have been detected in raw milk and traditional dairy products in Ghana [81] and Cote d'Ivoire [82]. Listeria monocytogenes, among other human pathogens, is considered a major microbiological and public threat associated with consumption of raw milk. L. monocytogenes has traditionally been a major public health issue in temperate regions including Europe and the US, particularly, due to their ability to grow at low temperature environments [83]. However, they have recently been isolated from different animal and milk products across Africa. The prevalence and characteristics of L. monocytogenes in raw milk and traditional dairy products in Ghana has been reported [84]. L. monocytogenes has also been recently reported to be prevalent in milk from other African countries including Egypt [85], Nigeria [86], Morocco [87] and Tanzania [76]. Other pathogens that have been detected in milk and milk products in Africa include Campylobacter jejuni [88], K. pneumonia [89] and S. aureus [90,91].

\section{Factors that Potentially Contribute to the Safety of Milk and Dairy Products in Africa}

\subsection{Natural Antimicrobial Systems in Milk}

Generally, raw milk contains natural antimicrobial peptides and enzymes including lactoferrin, lactoperoxidase, lysozyme and $\mathrm{N}$-acetyl- $\beta$-D-glucosaminidase, which may enhance the microbial safety of raw milk. These natural inhibitory systems in milk may prevent a significant increase in microbial loads within the first 3-4 h after harvesting milk at ambient temperatures [92]. These natural antimicrobials inhibit postharvest bacterial growth in the raw milk, thereby protecting consumers of raw milk against pathogenic microorganisms.

Lactoferrin is a glycoprotein with two binding sites for iron, and is found predominantly in colostrum, milk and other mammalian body secretions such as saliva, vaginal and seminal fluids and tears [93-95]. Lactoferrins present in bovine milk vary in amino acid composition but generally 
constitute about 3\% of the total milk protein [96]. In the colostrum, lactoferrin concentration is higher in both human and cow milk but decreases during the lactation period to insignificant levels. Several studies have reported on the physiological and antimicrobial functions of lactoferrins [94,97-99]. The antimicrobial effects of lactoferrin can be direct through bacteriostatic and bactericidal activity or indirect through activation of a complex series of reactions that lead to a protective immune response following microbial infections [100,101]. In vitro experiments and other studies have proven that one mechanism underlying the antimicrobial properties of lactoferrin is due to the iron-chelating property, which deprives microbes of iron, an essential nutrient necessary for growth. Thus, the bacteriostatic effect of lactoferrin is lost upon saturation of lactoferrin with iron [102-104]. Sometimes, however, the iron-chelating property of lactoferrin results in the death of some bacteria but encourages the growth of other bacteria with low iron requirement for growth [101,105]. Another mechanism for the antimicrobial property of lactoferrin is the direct interaction of intact or partially hydrolysed lactoferrin with lipopolysaccharide of the microbial cell, which may disrupt the cell wall integrity through dispersion of lipopolysaccharides, resulting in cell lysis $[93,106,107]$. Lactoferrin was found to inhibit the growth of E. coli and P. aeruginosa at concentrations of $0.67 \mathrm{mg} / \mathrm{mL}$, $1.67 \mathrm{mg} / \mathrm{mL}$ and $2.67 \mathrm{mg} / \mathrm{mL}$ but not $S$. aureus, K. pneumonia and coagulase-negative staphylococci isolated from a mastitic bovine udder [94]. Lactoferrin indirectly plays a role in cellular defence against microbial invasion by influencing the production of lymphocytes and macrophage activities [107]. Generally, the antimicrobial activities of lactoferrins are not significantly affected by commercial pasteurisation. However, treatments above temperatures used for pasteurisation can lead to their inactivation [108-110]. Thus, lactoferrins may contribute to the safety of raw or pasteurized milk and can complement-but cannot substitute-good hygienic practices in milk production and processing.

Lactoperoxidase, also known as milk peroxidase, is one of the heat-stable enzymes which is initially present at low concentrations in cow colostrum but increases after delivery. Like peroxidase found in tears, saliva, intestinal as well as nasal and bronchial, lactoperoxidase plays a protective role in the mammary gland, preventing microbial invasion [111]. In milk, lactoperoxidase alone has no significant antimicrobial activity. However, in the presence of hydrogen peroxide, lactoperoxidase causes the oxidation of thiocyanate ions into hypothiocyanous acid, which dissociates quickly in raw milk to hypothiocyanite ions. These hypothiocyanite ions are transient but have potent bacteriostatic effect against most mesophilic bacteria present in raw milk when oxidized by free sulphydryl groups. This occurs due to inactivation of important metabolic enzymes in bacteria consequently shutting down the cell metabolism and hence cell growth. This natural system is known as the lactoperoxidase system (LP-system). Lactoperoxidase is also reported to possess antiviral activity [112,113]. Activation of the LP-system helps to slow down microbial growth while transporting raw milk in remote areas having real difficulties with the application and maintenance of a cold chain system by smallholder dairy producers as pertains in many parts of Africa. The FAO/WHO in exploring ways to increase milk availability in Mali used thiocyanate and hydrogen peroxide to reactivate lactoperoxidase in raw milk. This treatment inhibited bacterial growth at ambient temperature, enabling milk to be transported to collection centres without spoilage losses and safety problems [114]. However, other safety concerns regarding the use of such system to preserve milk exist. Consequently, the FAO/WHO recommended that milk treated with the lactoperoxidase system should not be traded in the international market, that the use of the lactoperoxidase system should not be a substitute for pasteurization where possible, and that proper refrigeration and good hygiene should be practiced for securing the safety and quality of milk [115].

Lysozyme is another enzyme in milk, which acts synergistically with other antimicrobials to enhance the safety of raw milk. Lysozyme occurs in low concentrations in bovine raw milk but these levels are not reduced during pasteurisation because the enzyme is heat stable [116-118]. However, cows infected with mastitis have significantly higher concentrations of lysozyme in their raw milk compared to noninfected cows. The antibacterial activity of lysozyme is effective when working together with lactoferrin or immunoglobin A. For instance, the growth of E. coli was inhibited 
by the action of lysozyme and immunoglobin A [119]. Lysozyme causes lysis of some Salmonella spp. in association with ascorbate and peroxide, both of which are present in low concentrations in milk. However, lysozyme alone as a biopreservative at concentrations up to $5 \mathrm{mg} / \mathrm{mL}$, was not successful at inhibiting the growth and biofilm formation of S. aureus isolated from raw milk and cheese [120].

\subsection{Traditional Milk Processing Methods}

Throughout Africa, raw milk is processed into various traditional products including yoghurts and cheeses $[33,34,121-123]$. The main risks associated with the consumption of raw milk or its products are mainly of a microbiological nature. It has been shown that consumption of raw unpasteurized milk and its products pose realistic health threats due to possible contamination with human pathogens [14]. Therefore, it is prudent that various precautionary measures are put in place during production, handling and processing of milk to ensure safety of consumers.

Traditional processing of milk in Africa employs various unit operations or techniques which may enhance the safety of milk. These processing techniques or operations include thermal treatments, fermentation, or the use of other antimicrobials additives during processing. In the following sections, we explore the potential roles of these traditional processing techniques in enhancing the safety of milk products in Africa.

\subsubsection{Heat Treatment}

The microbial risks associated with the consumption of raw milk can be significantly reduced or completely eliminated by heat treatment. To prevent over-growth of surviving pathogens that contaminate the milk during harvest or incidental recontaminations during processing, pasteurization and temperature control (rapid cooling, chilled storage) are critical control points for foodborne pathogens associated with milk [124]. Previous data provide convincing evidence that adequate pasteurization of milk enhances safety and improves public health $[125,126]$. Depending on the time-temperature combinations applied, heat treatment of milk can be categorized as thermization $\left(57^{\circ} \mathrm{C}-68^{\circ} \mathrm{C}\right.$ for $\left.15-20 \mathrm{~s}\right)$, pasteurization $\left(60{ }^{\circ} \mathrm{C}-65^{\circ} \mathrm{C}\right.$ for $30 \mathrm{~m}$ or $71-74{ }^{\circ} \mathrm{C}$ for $\left.15-40 \mathrm{~s}\right)$ or sterilization $\left(110{ }^{\circ} \mathrm{C}-120^{\circ} \mathrm{C}\right.$ for $10-20 \mathrm{~min}$ ) which includes ultra-high temperature (UHT; $135-140{ }^{\circ} \mathrm{C}$ for $6-10 \mathrm{~s}$ for indirect and $140-150^{\circ} \mathrm{C}$ for $2-4 \mathrm{~s}$ for direct UHT) and innovative steam injection (ISI; $150-20{ }^{\circ} \mathrm{C}$ for $<0.1 \mathrm{~s}$ ) treatments. Each of these heat treatments of milk aim at different microbial targets and result in different shelf-life of the treated milk [125]. For example, thermization generally leads to only a 3-4 log reduction in the counts of the vegetative commensal microorganisms such as Aeromonas spp., coliform bacteria, Enterobacter spp., Micrococcus spp. and Pseudomonas spp., of milk, but does not completely inactivate all vegetative pathogens. On the other hand, pasteurization can eliminate all vegetative microorganisms, including vegetative human pathogenic cells of E. coli, Salmonella spp., L. monocytogenes, Yersinia enterocolitica, Campylobacter jejuni, enterotoxin producing S. aureus and Clostridium botulinum which may be present in raw milk [125]. However, pasteurization does not destroy preformed heat-resistant enterotoxins of $S$. aureus and C. botulinum B toxin and the emetic toxins (cereulide) of Bacillus cereus. Similarly, pasteurization neither destroys the heat-resistant spores of C. botulinum nor of B. cereus. Therefore, in order to destroy vegetative as well as spores of most pathogens, sterilization treatments are ideal. With the exception of spores of some nonpathogenic thermoresistant bacilli, sterilization can destroy spores of most pathogens including those of C. botulinum and B. cereus. Additionally, preformed toxins of $S$. aureus and C. botulinum in milk and the enterotoxins of B. cereus can be destroyed by sterilization techniques [125].

Refrigeration is often not accessible to traditional smallholder milk producers and processors in most rural communities in Africa due to the high initial investment and running costs, and technical problems such as the lack or unreliable supply of electricity. Therefore, boiling or heating raw milk is commonly practiced to improve the safety of milk before consumption by destroying or reducing the growth of pathogenic and spoilage microorganisms. Thus, it is common for milk to be heated several times as a means of preservation before consumption or further processing into other 
traditional products, a practice that arguably reduces the sensory properties and nutritional value of milk. Also, during the production of African fermented dairy products, raw milk is often boiled or pasteurized for safety and various technological reasons. For example, during the production of nyarmie and fènè, fermented yoghurt-like products in Ghana and Mali, respectively, raw cow milk is heated up to between $65^{\circ} \mathrm{C}$ and $80^{\circ} \mathrm{C}$ for about $30-50 \mathrm{~min}[34,127]$. Similarly, raw milk may be heated before fermentation occurs in the traditional processing of milk into amabre and mursik in Kenya [128,129], makamo in Uganda [130] and Pendidaam in Cameroon [131,132]. Although the temperature-time combinations used in heating milk in traditional African milk processing are not properly controlled, they can be considered generally as pasteurization, and are therefore capable of completely destroying most spoilage and vegetative human pathogens which may contaminate raw milk [125]. This method however, may be inefficient dependent on the microbial source of contamination or if initial levels of microbial contamination are high, e.g. pasteurization of milk at $72{ }^{\circ} \mathrm{C}$ for $15 \mathrm{~s}$ was found to be inadequate to render the milk safe due to the high initial counts of bacterial contamination [133].

\subsubsection{Natural Fermentation}

For the majority of smallholder dairy farmers and milk processors in Africa, fermentation of milk is the cheapest and most convenient method to prolong the shelf-life of milk. Traditional dairy fermentations in Africa are generally spontaneous or completed by back-slopping [34,121]. Thus, these processes do not involve the use of properly defined starter cultures and the fermentation takes place under poorly controlled conditions such as temperature and time. The fermentation process is initiated and carried out by commensal microorganisms present in collection and fermentation containers, the environment or from the hands of processors. Lactic acid bacteria (LAB) and yeasts are predominantly involved in traditional African fermentation of dairy products [34,122,127,134-137].

Traditional African fermented foods are generally considered to be safe due to the production of antimicrobial compounds by fermenting bacteria and the reduction in $\mathrm{pH}$ which contribute to inhibiting the growth of pathogenic microorganisms. The metabolic activities of LAB and yeasts results in a considerable decrease in $\mathrm{pH}$ due to production of organic acids (lactic and acetic acids). Additionally, compounds such as diacetyl, hydrogen peroxide and carbon dioxide are produced during LAB and yeasts fermentation [138-140]. These organic acids, together with the other compounds, act in synergy as antimicrobials, interfering with various metabolic activities of many pathogenic microorganisms by reducing their internal $\mathrm{pH}$, altering their cell membrane potential and inhibiting active transport, destroying membrane integrity by peroxidation of membranes lipids and denaturing enzymes and DNA [141-143]. However, depending on the species and strains of fermenting bacteria, varying amounts of these compounds are produced during milk fermentation. For example, cell-free cultures supernatant of lactic acid bacteria (LAB) strains isolated from nunu, exhibited varying degrees of inhibition against indicator pathogenic strains i.e., B. cereus PA24, S. aureus ATCC 19095, E. coli O157:H7, L. monocytogenes ScottA, Salmonella enterica Typhimurium ATCC 13311, and Pseudomonas aeruginosa BFE 162. Notably, Lb. fermentum (10\%), Lb. plantarum (27\%), Lb. helviticus (31\%), Leuconostoc mesenteroides $(20 \%)$, and Enterococcus italicus (5\%) exhibited the greatest zones of inhibition [144]. Furthermore, a considerable reduction in counts or complete elimination of Enterobacteriaceae during spontaneous fermentation of milk to produce nunu in rural communities in Ghana has been reported [145].

Other antimicrobial compounds produced during the fermentation of milk such as diacetyl, hydrogen peroxide and bacteriocins have various degrees of antimicrobial activities against potential food spoilage microorganisms. Generally, diacetyl is produced in low concentrations by some $\mathrm{LAB}$ as part of their metabolic activities. The antimicrobial activity of diacetyl is enhanced when used synergistically with other antimicrobials such as hydrogen peroxide. Bacteriocins, on the other hand are antimicrobial peptides produced by some bacteria, and typically show activity against closely related species whereas the producer bacteria are unaffected because they possess specific protective mechanisms [146]. Some bacteriocins as nisin has antimicrobial activity against 
both gram positive and gram-negative bacteria [147], and can inhibit sporulation in bacilli and clostridia [148,149]. Lactic acid bacteria isolated from milk have shown the capacity to produce great diversity of bacteriocins [150]. Bacteriocin-producing cultures can be inoculated in situ as starter or adjunct cultures [35,151], or purified bacteriocins can be added ex situ [152] to improve safety of milk and dairy products. Currently, the commercial application of nisin (Nisaplin, Danisco, Denmark), and pediocin PA1 (MicrogardTM, ALTA 2431, Quest International, USA) as bio-preservative in the dairy industry are accepted. Nisin in synergy with other antimicrobials such as LysH5, the endolysin encoded by staphylococcal bacteriophages, showed strong inhibitory activity towards S. aureus Sa9 in-vitro [153]. The viability of strains together with growth conditions e.g. temperature, $\mathrm{pH}$ and water activity among others have been found to affect the effectiveness of the use of bacteriocin-producing strains as protective cultures in situ to control pathogens in dairy products [152]. Other LAB bacteriocins such as enterocin AS-48 [154] and lacticin 3147 [155], have shown promising prospects for commercial application as food bio-preservatives.

Fungal contamination of milk and dairy products can occur along the dairy production chain, posing severe problems, especially in areas where mycotoxin producing moulds frequently occur. However, fermentation by LAB has been reported to be important for the reduction in mycotoxin content. Thus, the antifungal property LAB strains can be exploited in inhibiting fungal growth in various of fermented milk products including yoghurts [156-158] and cheeses [159]. Significant reduction in mycotoxin (AFM1) content in contaminated milk was observed as it was processed into yoghurt, cheese and acidified milk [160]. Similar results were observed during the processing of raw milk into Egyptian domaiti cheese and subsequent storage for three months at $20^{\circ} \mathrm{C}$ [161]. The reduction in mycotoxin in fermented foods has been attributed to interference of mycotoxin production by LAB during the fermentation process [162]. In addition to the direct interference or production of antifungal compounds to inhibit fungal growth during fermentation, some LAB strains interact with fungal mycotoxins, leading to their inactivation or their removal through cell wall binding [163,164].

\subsubsection{Use of Antimicrobial Additives}

In order to inhibit the growth of pathogenic and spoilage microorganisms, traditional milk processing in certain parts of Africa employ the use of various medicinal plant parts or their extracts to serve as antimicrobial agents. For example, people of the Maasai community in Kenya add extracts of Lippia javanica (stem), olkingiri (stem) or Olea europea (root) to pasteurized milk before fermenting it into kule naoto. Pretreatment of the fermenting gourd with ashes or charcoal remains of Olea africana before filling it with pasteurized milk during the production of kule naoto improves the quality and enhances the safety of the milk product [165]. Microbial counts in plant extract-fermented milk were found to be lower than control, even though $\mathrm{pH}$ was higher in the plant extract-fermented milk [166]. During production of mursk, the gourd is somehow sanitized by burning sticks of Senna didymobotrya before filling it with pasteurized milk for fermentation [167]. Similarly, the fermentation of camel milk into suusac is preceded by smoking the gourd (fermentation vessel) with Acacia seyal [168], a process that is expected to eliminate pathogenic and spoilage microorganisms before the fermentation process takes place in order to ensure safety of the final product.

\section{Future Perspectives for Improving Food Safety}

Milk is highly prone to spoilage; and this challenge is exacerbated by the fact that the warm climate in Africa encourages the growth of both pathogenic and spoilage microorganisms in highly perishable foods like milk. Efforts to improve the microbial safety of milk and dairy products in Africa will require commitment from all key stakeholders in the dairy chain. 


\subsection{Role of Governments and Regulatory Bodies}

The role of governments in ensuring the safety of milk and dairy products includes setting the necessary safety standards, performing inspections and putting measures in place to ensure that the standards are met, and having a strong enforcement program. In this context, there is the need for governments in the African continent to set up and legislate laws and regulations on the handling of milk-from farm to cup. Some of the expected standards for milk will include milking under sanitary conditions, cooling milk to refrigeration temperatures (below $4{ }^{\circ} \mathrm{C}$ ) immediately after milking, transporting milk with vehicles equipped with appropriate cooling facilities, etc. Governments must also incentivise farmers by providing the access to necessary facilities. For example, the provision of centrally placed holding and distribution centres that are equipped with chilling and microbial testing facilities will ensure that milk travels only short distances from time of milking until cooling. This way, milk will not be subjected to significant temperature abuse that promotes spoilage, thus assuring that the milk fed into the food system is safe. There should also be functioning surveillance measures and systems to track and halt the carrying of contaminated milk into the dairy chain, and these surveillance systems must be accessible by the general public. Governments should also perform outbreak investigations to identity sources of contamination in the dairy chain, new pathogens and their food vehicles, as well as gaps in the dairy chain that compromise on food safety. Such investigations can be done in partnership with various academic and research institutions who can use the findings in the training of the next generation of food safety and control staff in the fields of food science, food technology, agriculture and biology. It is worth noting that governments must upgrade the requirements for food safety to support other important requirements such as economic implications (e.g., economic risks that arise from food spoilage), trade partnerships and agreements. Finally, to develop lifelong safe food handling habits among the populace, governments would need to implement a wholistic food safety and hygiene as part of the education curricula beginning with junior and senior high schools to improve food safety cognition among students and promote long-term safe food-handling behaviour.

\subsection{Role of Dairy Chain Actors}

Dairy farmers, distributors and milk processors play the most important role in ensuring the safety of milk and dairy products. The average African dairy farmer must have the knowledge and training in preventive approaches such as hazard analysis and critical control points (HACCP) design and implementation, good hygienic practices (GHPs), and good manufacturing practices (GMPs) in the handling of milk. Knowledge on the use of simple equipment such as mastitis detectors to assess the health of cows, and resazurin kits to estimate microbial loads in milk are also important. Dairy farmers must also have knowledge on good agricultural practices (GAPs) that include good milking practices, humane treatment of cows to promote animal health, ensuring that cows are only fed safe feed and water etc. Farmers will also need to liaise with the necessary governmental bodies to run surveillance systems and ensure an effective recall program in the event that milk is found to be contaminated. Agricultural extension officers can assist with the training of farmers in food quality assurance and management programs. In this regard, farmers and extension officers can peruse training modules and documents produced by FAO, as these documents contain useful information that are feasible for the implementation in resource-poor settings.

Milk distributors and dairy processors also have a role to play in ensuring the safety of milk in the dairy chain. Processing of milk via fermentation into yoghurts, cheeses and other fermented products should be carried out using well defined starter cultures rather than by spontaneous fermentation [169]. The use of starter culture is known to promote consistency in the quality of products [170], shorten fermentation time [171], guarantee product safety [172,173], and allows for the adoption of predictive microbiology principles. Predictive microbiology operates on the assumption that microorganisms will behave (grow and metabolize compounds) in a predictable way under similar environmental conditions ( $\mathrm{pH}$, temperature, 
water activity, etc), making it possible to assess, forecast and quantify microbial populations and their products as a function of environmental conditions [174,175].

Moreover, distribution outlets will need to be equipped with the necessary facilities for rapid cooling, pasteurisation, testing for microbial load, and cold transportation of milk. Cold storage and transportation of foods in Africa is a challenge. This is not only because of the warm and humid climate in the continent, but also because many countries in Africa experience erratic power supply [176,177], making it difficult to keep products in cold storage for extended periods of time. This said, there are several innovative technologies and bespoke cooling equipment that can be adopted and used in the dairy sector in Africa. Examples of these include evaporative cooling chambers, also called zero energy cool chambers [178]. However, their value in the dairy chain still needs to be proved. Other innovative technologies that could be useful for ensuring microbial safety in the dairy chain include the development of electricity-independent and solar-powered fridges. Finally, consumers have the responsibility to educate themselves in food safety principles, follow labelling instructions and obey "use by" dates on dairy products. They must also keep up to date with dairy surveillance systems published by government and food processors and demand safe and quality milk and dairy products from suppliers.

\section{Conclusions}

The consumption of unpasteurized milk and dairy products continue to pose significant health risk to consumers due to the persistence of microbial pathogens of significant safety concern in the dairy chain in Africa. Notwithstanding, the production and consumption of milk in Africa is projected to grow in the next few decades. While this forecast has positive economic and nutritional prospects for the continent, it also raises serious concerns for public health, considering that milk and dairy products in Africa are frequently contaminated with pathogenic microorganisms. Therefore, there is the need to deliberately put in place systems to ensure the safety of milk and dairy products in the African continent to avert any future detrimental health and economic impact. To minimize the health risks associated with the consumption of milk and dairy products, all food-chain operators, including dairy farmers, processors, distributors, retailers and consumers would need to take the required steps to maintain food-safety. Governments and regulatory agencies have a crucial role to play in engaging with all stakeholders to establish national and regional controls and standards, including inspection and surveillance to ensure effective controls and conditions for safe production, transportation and storage of milk and dairy products. The establishment and implementation of control measures and standards should also take into account the unique characteristic of the dairy chain in the particular African country. Recognition of smallholder dairying and informal markets through training and certification would be very significant in ensuring the safety of milk and dairy products. The role of education in ensuring production, distribution and processing of safe milk cannot be overemphasized. If consumers are well-informed about the dangers of consuming contaminated milk, they will demand the highest safety standards from the milk distributors and regulatory authorities. The outcome of all these would be a well-functioning dairy system that not only brings economic incentives, but also protects the health of the consumers.

Author Contributions: J.O.-K. conceptualized and designed the manuscript. J.O.-K., F.A., D.A., and L.J. wrote the manuscript. L.J. critically reviewed and edited the manuscript. All authors have read and agreed to the published version of the manuscript.

Funding: This research received no external funding.

Conflicts of Interest: The authors declare no conflict of interest. 


\section{References}

1. Dirar, H.A. The Indigenous Fermented Foods of the Sudan: A Study in African Food and Nutrition; CAB International: Wallingford, UK, 1993.

2. Fratkin, E. Seeking alternative livelihoods in pastoral areas. In Pastoralism and Development in Africa: Dynamic Change at the Margins New York; Routledge: Abingdon, UK, 2013.

3. Wurzinger, M.; Okeyo, A.M.; Semambo, D.; Souml, J. The sedentarisation process of the Bahima in Uganda: An emic view. Afric. J. Agric. Res. 2009, 4, 1154-1158.

4. Schönfeldt, H.C.; Hall, N.G. Dietary protein quality and malnutrition in Africa. Br. J. Nutr. 2012, 108, S69-S76. [CrossRef] [PubMed]

5. Wuehler, S.E.; Hess, S.Y.; Brown, K.H. Accelerating improvements in nutritional and health status of young children in the Sahel region of Sub-Saharan Africa: Review of international guidelines on infant and young child feeding and nutrition. Matern. Child. Nutr. 2011, 7, 6-34. [CrossRef] [PubMed]

6. Quigley, L.; O'Sullivan, O.; Stanton, C.; Beresford, T.P.; Ross, R.P.; Fitzgerald, G.F.; Cotter, P.D. The complex microbiota of raw milk. FEMS Microbiol. Rev. 2013, 37, 664-698. [CrossRef]

7. Muehlhoff, E.; Bennett, A.; McMahon, D. Milk and Dairy Products in Human Nutrition; Food and Agriculture Organization of the United Nations (FAO): Rome, Italy, 2013.

8. Oliver, S.P.; Jayarao, B.M.; Almeida, R.A. Foodborne pathogens in milk and the dairy farm environment: Food safety and public health implications. Foodbourne Pathog. Dis. 2005, 2, 115-129. [CrossRef]

9. Kenny, M. Safety and quality. In Milk and Dairy Products in Human Nutrition; FAO: Rome, Italy, 2013; pp. 243-273.

10. De Leeuw, P.; Omore, A.; Staal, S.; Thorpe, W. Dairy production systems in the tropics. In Smallholder Dairying in the Tropics. ILRI. ACC. no. IL-990209; International Livestock Research Institute: Nairobi, Kenya, 1999; pp. $19-44$.

11. Omore, A.O.; Staal, S.J.; Kurwijila, L.R.; Osafo, E.; Aning, G.; Mdoe, N.; Nurah, G. Indigenous markets for dairy products in Africa: Trade-offs between food safety and economics. In Proceedings of the Symposium on Dairy Development in the Tropics, Utrecht University, Utrecht, The Netherlands, 2 November 2001; pp. 19-24.

12. FAO/WHO. General principles of food hygiene, CAC/RCP 1-1969, Rev. 4 (2003); FAO: Rome, Italy, 2003.

13. FAO/WHO; Codex Committee on Food Additives and Contaminants. Proposed Draft Code of Practice for the Prevention and the Reduction of Dioxin and Dioxin-Like PCB Contamination in Foods and Feeds; FAO: Rome, Italy, 2006.

14. Verraes, C.; Vlaemynck, G.; Van Weyenberg, S.; De Zutter, L.; Daube, G.; Sindic, M.; Uyttendaele, M.; Herman, L. A review of the microbiological hazards of dairy products made from raw milk. Int. Dairy J. 2015, 50, 32-44. [CrossRef]

15. Angulo, F.J.; LeJeune, J.T.; Rajala-Schultz, P.J. Unpasteurized milk: A continued public health threat. Clin. Infect. Dis. 2009, 48, 93-100.

16. Batavani, R.; Asri, S.; Naebzadeh, H. The effect of subclinical mastitis on milk composition in dairy cows. Iran. J. Vet. Res. 2007, 8, 205-211.

17. Sharma, A.; Chhabra, R.; Sindhu, N. Prevalence of sub clinical mastitis in cows: Its etiology and antibiogram. Indian J. Anim. Res. 2012, 46, 348-353.

18. Sharma, N.; Maiti, S.; Sharma, K.K. Prevalence, etiology and antibiogram of microorganisms associated with Sub-clinical mastitis in buffaloes in Durg, Chhattisgarh State (India). Int. J. Dairy Sci. 2007, 2, 145-151.

19. Tiwari, J.; Babra, C.; Tiwari, H.; Williams, V.; De Wet, S.; Gibson, J.; Paxman, A.; Morgan, E.; Costantino, P.; Sunagar, R. Trends in therapeutic and prevention strategies for management of bovine mastitis: An overview. J. Vaccines Vaccin. 2013, 4, 1-11. [CrossRef]

20. Katsande, S.; Matope, G.; Ndengu, M.; Pfukenyi, D.M. Prevalence of mastitis in dairy cows from smallholder farms in Zimbabwe. Onderstepoort J. Vet. Res. 2013, 80, 523. [CrossRef] [PubMed]

21. Kivaria, F.; Noordhuizen, J.; Kapaga, A. Risk indicators associated with subclinical mastitis in smallholder dairy cows in Tanzania. Trop. Anim. Health Prod. 2004, 36, 581-592. [CrossRef] [PubMed]

22. Lakew, M.; Tolosa, T.; Tigre, W. Prevalence and major bacterial causes of bovine mastitis in Asella, South Eastern Ethiopia. Trop. Anim. Health Prod. 2009, 41, 1525. [CrossRef] 
23. Mpatswenumugabo, J.P.; Bebora, L.C.; Gitao, G.C.; Mobegi, V.; Iraguha, B.; Kamana, O.; Shumbusho, B. Prevalence of subclinical mastitis and distribution of pathogens in dairy farms of Rubavu and Nyabihu districts, Rwanda. J. Vet. Med. 2017, 2017. [CrossRef]

24. Girma, S.; Mammo, A.; Bogele, K.; Sori, T.; Tadesse, F.; Jibat, T. Study on prevalence of bovine mastitis and its major causative agents in West Harerghe zone, Doba district, Ethiopia. J. Vet. Med. Anim. Health 2012, 4, 116-123.

25. Magnusson, M.; Christiansson, A.; Svensson, B.; Kolstrup, C. Effect of different premilking manual teat-cleaning methods on bacterial spores in milk. J. Dairy Sci. 2006, 89, 3866-3875. [CrossRef]

26. Van Gastelen, S.; Westerlaan, B.; Houwers, D.; Van Eerdenburg, F. A study on cow comfort and risk for lameness and mastitis in relation to different types of bedding materials. J. Dairy Sci. 2011, 94, 4878-4888. [CrossRef]

27. Vissers, M.; Driehuis, F.; Te Giffel, M.; De Jong, P.; Lankveld, J. Minimizing the level of butyric acid bacteria spores in farm tank milk. J. Dairy Sci. 2007, 90, 3278-3285. [CrossRef]

28. Sudhan, N.; Sharma, N. Mastitis-An Important Production Disease of Dairy Animals; Sarva Manav Vikash Samiti: Gurgoan, India, 2010; pp. 72-88.

29. Abrahmsén, M.; Persson, Y.; Kanyima, B.M.; Båge, R. Prevalence of subclinical mastitis in dairy farms in urban and peri-urban areas of Kampala, Uganda. Trop. Anim. Health Prod. 2014, 46, 99-105. [CrossRef]

30. Dego, O.K.; Tareke, F. Bovine mastitis in selected areas of southern Ethiopia. Trop. Anim. Health Prod. 2003, 35, 197-205. [CrossRef] [PubMed]

31. Mungube, E.; Tenhagen, B.-A.; Kassa, T.; Regassa, F.; Kyule, M.; Greiner, M.; Baumann, M. Risk factors for dairy cow mastitis in the central highlands of Ethiopia. Trop. Anim. Health Prod. 2004, 36, 463-472. [CrossRef] [PubMed]

32. Karimuribo, E.; Gallet, P.; Ng'umbi, N.; Matiko, M.; Massawe, L.; Mpanduji, D.; Batamuzi, E. Status and factors affecting milk quality along the milk value chain: A case of Kilosa district, Tanzania. Livest. Res. Rural Dev. 2015, 27, 51 .

33. Mattiello, S.; Caroprese, M.; Matteo, C.G.; Fortina, R.; Martini, A.; Martini, M.; Parisi, G.; Russo, C.; Zecchini, M. Typical dairy products in Africa from local animal resources. Ital. J. Anim. Sci. 2018, 17, 740-754. [CrossRef]

34. Owusu-Kwarteng, J.; Akabanda, F.; Johansen, P.; Jespersen, L.; Nielsen, D.S. Nunu, A West African Fermented Yogurt-Like Milk Product. In Yogurt in Health and Disease Prevention; Shah, N.P., Ed.; Elsevier Academic Publisher: London, UK, 2017.

35. Holzapfel, W. Appropriate starter culture technologies for small-scale fermentation in developing countries. Int. J. Food Microbiol. 2002, 75, 197-212. [CrossRef]

36. Josephsen, J.; Jespersen, L. Starter cultures and fermented products. In Handbook of Food and Beverage Fermentation Technology; CRC Press: Marcel Dekker, NY, USA, 2004; pp. 39-66.

37. Ducrotoy, M.; Bertu, W.; Matope, G.; Cadmus, S.; Conde-Álvarez, R.; Gusi, A.; Welburn, S.; Ocholi, R.; Blasco, J.; Moriyón, I. Brucellosis in Sub-Saharan Africa: Current challenges for management, diagnosis and control. Acta Trop. 2017, 165, 179-193.

38. Michel, A.L.; Geoghegan, C.; Hlokwe, T.; Raseleka, K.; Getz, W.M.; Marcotty, T. Longevity of Mycobacterium bovis in raw and traditional souring milk as a function of storage temperature and dose. PLoS ONE 2015, 10, e0129926. [CrossRef]

39. Pexara, A.; Solomakos, N.; Govaris, A. Q fever and prevalence of Coxiella burnetii in milk. Trends Food Sci. Technol. 2018, 71, 65-72. [CrossRef]

40. Vanderburg, S.; Rubach, M.P.; Halliday, J.E.; Cleaveland, S.; Reddy, E.A.; Crump, J.A. Epidemiology of Coxiella burnetii infection in Africa: A OneHealth systematic review. PLoS Negl. Trop. Dis. 2014, 8, e2787. [CrossRef]

41. Yilma, M.; Mamo, G.; Mammo, B. Review on brucellosis sero-prevalence and ecology in livestock and human population of Ethiopia. Achiev. Life Sci. 2016, 10, 80-86. [CrossRef]

42. Sichewo, P.R.; Etter, E.M.C.; Michel, A.L. Prevalence of Mycobacterium bovis infection in traditionally managed cattle at the wildlife-livestock interface in South Africa in the absence of control measures. Vet. Res. Commun. 2019, 43, 155-164. [CrossRef] [PubMed] 
43. Machado, A.; Rito, T.; Ghebremichael, S.; Muhate, N.; Maxhuza, G.; Macuamule, C.; Moiane, I.; Macucule, B.; Marranangumbe, A.S.; Baptista, J. Genetic diversity and potential routes of transmission of Mycobacterium bovis in Mozambique. PLoS Negl. Trop. Dis. 2018, 12, e0006147. [CrossRef] [PubMed]

44. Ogundeji, E.; Onyemelukwe, N.; Nwuko, A.; Onuoha, M.; Ogundeji, A.; Osaretin, J.; Eze, K.; Olofu, J.; Jik, A.; Kemza, S. Molecular detection of Mycobacterium bovis in cattle milk in Enugu State, Nigeria. J. Nat. Sci. Res. 2015, 5, 42-47.

45. Kahla, I.B.; Boschiroli, M.; Souissi, F.; Cherif, N.; Benzarti, M.; Boukadida, J.; Hammami, S. Isolation and molecular characterisation of Mycobacterium bovis from raw milk in Tunisia. Afr. Health Sci. 2011, 11, 2-5.

46. Pandey, G.S.; Hang'ombe, B.M.; Mushabati, F.; Kataba, A. Prevalence of tuberculosis among southern Zambian cattle and isolation of Mycobacterium bovis in raw milk obtained from tuberculin positive cows. Vet. World 2013, 6, 986. [CrossRef]

47. Ayele, W.; Neill, S.; Zinsstag, J.; Weiss, M.; Pavlik, I. Bovine tuberculosis: An old disease but a new threat to Africa. Int. J. Tuberc. Lung Dis. 2004, 8, 924-937.

48. Müller, B.; Dürr, S.; Alonso, S.; Hattendorf, J.; Laisse, C.J.; Parsons, S.D.; Van Helden, P.D.; Zinsstag, J. Zoonotic Mycobacterium bovis-induced tuberculosis in humans. Emerg. Infect. Dis. 2013, 19, 899. [CrossRef]

49. Olea-Popelka, F.; Muwonge, A.; Perera, A.; Dean, A.S.; Mumford, E.; Erlacher-Vindel, E.; Forcella, S.; Silk, B.J.; Ditiu, L.; El Idrissi, A. Zoonotic tuberculosis in human beings caused by Mycobacterium bovis-A call for action. Lancet Infect. Dis 2017, 17, e21-e25. [CrossRef]

50. Angelakis, E.; Raoult, D. Q fever. Vet. Microbiol. 2010, 140, 297-309. [CrossRef]

51. Eldin, C.; Melenotte, C.; Million, M.; Cammilleri, S.; Sotto, A.; Elsendoorn, A.; Thuny, F.; Lepidi, H.; Roblot, F.; Weitten, T. 18F-FDG PET/CT as a central tool in the shift from chronic $\mathrm{Q}$ fever to Coxiella burnetii persistent focalized infection: A consecutive case series. Medicine 2016, 95, e4287. [CrossRef]

52. Klaasen, M.; Roest, H.-J.; van der Hoek, W.; Goossens, B.; Secka, A.; Stegeman, A. Coxiella burnetii seroprevalence in small ruminants in The Gambia. PLoS ONE 2014, 9, e85424. [CrossRef] [PubMed]

53. Breurec, S.; Poueme, R.; Fall, C.; Tall, A.; Diawara, A.; Bada-Alambedji, R.; Broutin, C.; Leclercq, A.; Garin, B. Microbiological quality of milk from small processing units in Senegal. Foodborne Pathog. Dis. 2010, 7, 601-604. [CrossRef] [PubMed]

54. Loftis, A.D.; Priestley, R.A.; Massung, R.F. Detection of Coxiella burnetii in commercially available raw milk from the United States. Foodborne Pathog. Dis. 2010, 7, 1453-1456. [CrossRef] [PubMed]

55. Prabhu, M.; Nicholson, W.L.; Roche, A.J.; Kersh, G.J.; Fitzpatrick, K.A.; Oliver, L.D.; Massung, R.F.; Morrissey, A.B.; Bartlett, J.A.; Onyango, J.J. Q fever, spotted fever group, and typhus group rickettsioses among hospitalized febrile patients in northern Tanzania. Clin. Infect. Dis. 2011, 53, e8-e15. [CrossRef]

56. Crump, J.A.; Morrissey, A.B.; Nicholson, W.L.; Massung, R.F.; Stoddard, R.A.; Galloway, R.L.; Ooi, E.E.; Maro, V.P.; Saganda, W.; Kinabo, G.D. Etiology of severe non-malaria febrile illness in Northern Tanzania: A prospective cohort study. PLoS Negl. Trop. Dis. 2013, 7, e2324. [CrossRef]

57. Koulla-Shiro, S.; Kuaban, C.; Bélec, L. Microbial etiology of acute community-acquired pneumonia in adult hospitalized patients in Yaounde-Cameroon. Clin. Microbiol. Infect. 1997, 3, 180-186. [CrossRef]

58. Al Dahouk, S.; Köhler, S.; Occhialini, A.; De Bagüés, M.P.J.; Hammerl, J.A.; Eisenberg, T.; Vergnaud, G.; Cloeckaert, A.; Zygmunt, M.S.; Whatmore, A.M. Brucella spp. of amphibians comprise genomically diverse motile strains competent for replication in macrophages and survival in mammalian hosts. Sci. Rep. 2017, 7, 44420. [CrossRef]

59. Corbel, M.J. Brucellosis in Humans and Animals; World Health Organization: Geneva, Switzerland, 2006; pp. 13-35.

60. Whatmore, A.M.; Davison, N.; Cloeckaert, A.; Al Dahouk, S.; Zygmunt, M.S.; Brew, S.D.; Perrett, L.L.; Koylass, M.S.; Vergnaud, G.; Quance, C. Brucella papionis sp. nov., isolated from baboons (Papio spp.). Int. J. Syst. Evol. Microbiol. 2014, 64, 4120. [CrossRef]

61. Doganay, M.; Aygen, B. Human brucellosis: An overview. Int. J. Infect. Dis. 2003, 7, 173-182. [CrossRef]

62. FAO. Brucella melitensis in Eurasia and the Middle East; FAO Animal Production and Health Proceedings. No. 10; FAO: Rome, Italy, 2010.

63. WHO. The Control. of Neglected Zoonotic Diseases: A Route to Poverty Alleviation; Report of a Joint WHO/DFID-AHP Meeting, 20 and 21 September 2005, WHO Headquarters; WHO: Geneva, Italy, 2005; pp. 1-54. 
64. Musallam, I.; Ndour, A.P.; Yempabou, D.; Ngong, C.-A.C.; Dzousse, M.F.; Mouiche-Mouliom, M.-M.; Feussom, J.M.K.; Ntirandekura, J.B.; Ntakirutimana, D.; Fane, A. Brucellosis in dairy herds: A public health concern in the milk supply chains of West and Central Africa. Acta Trop. 2019, 105042. [CrossRef]

65. Bonfoh, B.; Fane, A.; Steinmann, P.; Hetzel, M.; Traore, A.; Traore, M.; Simbe, C.; Alfaroukh, I.; Nicolet, J.; Akakpo, J. Qualité microbiologique du lait et des produits laitiers vendus au Mali et leurs implications en santé publique. Etudes et recherches sahéliennes 2003, 8, 19-27.

66. Caine, L.A.; Nwodo, U.U.; Okoh, A.I.; Green, E. Molecular characterization of Brucella species in cattle, sheep and goats obtained from selected municipalities in the Eastern Cape, South Africa. Asian Pac. J. Trop. Dis. 2017, 7, 293-298. [CrossRef]

67. Hoffman, T.; Rock, K.; Mugizi, D.R.; Muradrasoli, S.; Lindahl-Rajala, E.; Erume, J.; Magnusson, U.; Lundkvist, Å.; Boqvist, S. Molecular detection and characterization of Brucella species in raw informally marketed milk from Uganda. Infect. Ecol. Epidemiol. 2016, 6, 32442. [CrossRef] [PubMed]

68. Farougou, S.; Sessou, P.; Yehouenou, B.; Dossa, F. Microbiological quality of raw milk processed from cows raised under extensive system in the Republic of Benin. Res. J. Microbiol. 2012, 7, 337-343. [CrossRef]

69. Ahmed, A.M.; Shimamoto, T. Isolation and molecular characterization of Salmonella enterica, Escherichia coli O157: H7 and Shigella spp. from meat and dairy products in Egypt. Int. J. Food Microbiol. 2014, 168, 57-62. [CrossRef] [PubMed]

70. Ombarak, R.A.; Hinenoya, A.; Awasthi, S.P.; Iguchi, A.; Shima, A.; Elbagory, A.-R.M.; Yamasaki, S. Prevalence and pathogenic potential of Escherichia coli isolates from raw milk and raw milk cheese in Egypt. Int. J. Food Microbiol. 2016, 221, 69-76. [CrossRef]

71. Bedasa, S.; Shiferaw, D.; Abraha, A.; Moges, T. Occurrence and antimicrobial susceptibility profile of Escherichia coli O157: H7 from food of animal origin in Bishoftu town, Central Ethiopia. Int. J. Food Contam. 2018, 5, 2. [CrossRef]

72. Kunadu, A.P.-H.; Holmes, M.; Miller, E.L.; Grant, A.J. Microbiological quality and antimicrobial resistance characterization of Salmonella spp. in fresh milk value chains in Ghana. Int. J. Food Microbiol. 2018, 277, 41-49. [CrossRef]

73. Enabulele, S.; Nwankiti, O. Shiga Toxin (Stx) Gene detection and verotoxigenic potentials of non-0157 Escherichia coli isolated from fermented fresh cow milk (Nono) sold in selected cities in Nigeria. Nig. J. Basic Appl. Sci. 2016, 24, 98-105. [CrossRef]

74. Ivbade, A.; Ojo, O.E.; Dipeolu, M.A. Shiga toxin-producing Escherichia coli O157: H7 in milk and milk products in Ogun State, Nigeria. Vet. Ital. 2014, 50, 185-191.

75. Msolo, L.; Igbinosa, E.O.; Okoh, A.I. Prevalence and antibiogram profiles of Escherichia coli O157: H7 isolates recovered from three selected dairy farms in the Eastern Cape Province, South Africa. Asian Pac. J. Trop. Dis. 2016, 6, 990-995. [CrossRef]

76. Msalya, G. Contamination levels and identification of bacteria in milk sampled from three regions of Tanzania: Evidence from literature and laboratory analyses. Vet. Med. Int. 2017, 2017. [CrossRef] [PubMed]

77. Schoder, D.; Maichin, A.; Lema, B.; Laffa, J. Microbiological quality of milk in Tanzania: From Maasai stable to African consumer table. J. Food Prot. 2013, 76, 1908-1915. [CrossRef] [PubMed]

78. Knight-Jones, T.J.; Hang'ombe, M.B.; Songe, M.M.; Sinkala, Y.; Grace, D. Microbial contamination and hygiene of fresh cow's milk produced by smallholders in Western Zambia. Int. J. Environ. Res. Public Health 2016, 13, 737. [CrossRef] [PubMed]

79. Agata, N.; Ohta, M.; Yokoyama, K. Production of Bacillus cereus emetic toxin (cereulide) in various foods. Int. J. Food Microbiol. 2002, 73, 23-27. [CrossRef]

80. Sergeev, N.; Distler, M.; Vargas, M.; Chizhikov, V.; Herold, K.E.; Rasooly, A. Microarray analysis of Bacillus cereus group virulence factors. J. Microbiol. Methods 2006, 65, 488-502. [CrossRef]

81. Owusu-Kwarteng, J.; Wuni, A.; Akabanda, F.; Tano-Debrah, K.; Jespersen, L. Prevalence, virulence factor genes and antibiotic resistance of Bacillus cereus sensu lato isolated from dairy farms and traditional dairy products. BMC Microbiol. 2017, 17, 65. [CrossRef]

82. Yobouet, B.A.; Kouamé-Sina, S.M.; Dadié, A.; Makita, K.; Grace, D.; Djè, K.M.; Bonfoh, B. Contamination of raw milk with Bacillus cereus from farm to retail in Abidjan, Côte d'Ivoire and possible health implications. Dairy Sci Technol. 2014, 94, 51-60. [CrossRef] 
83. Buchanan, R.L.; Gorris, L.G.; Hayman, M.M.; Jackson, T.C.; Whiting, R.C. A review of Listeria monocytogenes: An update on outbreaks, virulence, dose-response, ecology, and risk assessments. Food Control. 2017, 75, 1-13. [CrossRef]

84. Owusu-Kwarteng, J.; Wuni, A.; Akabanda, F.; Jespersen, L. Prevalence and characteristics of Listeria monocytogenes isolates in raw milk, heated milk and nunu, a spontaneously fermented milk beverage, in Ghana. Beverages 2018, 4, 40. [CrossRef]

85. Tahoun, A.B.; Elez, R.M.A.; Abdelfatah, E.N.; Elsohaby, I.; El-Gedawy, A.A.; Elmoslemany, A.M. Listeria monocytogenes in raw milk, milking equipment and dairy workers: Molecular characterization and antimicrobial resistance patterns. J. Glob. Antimicrob. Resist. 2017, 10, 264-270. [CrossRef] [PubMed]

86. Usman, U.; Kwaga, J.; Kabir, J.; Olonitola, O. Isolation and antimicrobial susceptibility of Listeria monocytogenes from raw milk and milk products in Northern Kaduna State, Nigeria. J. Appl. Environ. Microbiol. 2016, 4, 46-54.

87. Amajoud, N.; Leclercq, A.; Soriano, J.M.; Bracq-Dieye, H.; El Maadoudi, M.; Senhaji, N.S.; Kounnoun, A.; Moura, A.; Lecuit, M.; Abrini, J. Prevalence of Listeria spp. and characterization of Listeria monocytogenes isolated from food products in Tetouan, Morocco. Food Control. 2018, 84, 436-441. [CrossRef]

88. El-Zamkan, M.A.; Hameed, K.G.A. Prevalence of Campylobacter jejuni and Campylobacter coli in raw milk and some dairy products. Vet. World 2016, 9, 1147. [CrossRef] [PubMed]

89. Walsh, A.M.; Crispie, F.; Daari, K.; O’Sullivan, O.; Martin, J.C.; Arthur, C.T.; Claesson, M.J.; Scott, K.P.; Cotter, P.D. Strain-level metagenomic analysis of the fermented dairy beverage nunu highlights potential food safety risks. Appl. Environ. Microbiol. 2017, 83, e01144-e17. [CrossRef]

90. Beyene, T.; Hayishe, H.; Gizaw, F.; Beyi, A.F.; Abunna, F.; Mammo, B.; Ayana, D.; Waktole, H.; Abdi, R.D. Prevalence and antimicrobial resistance profile of Staphylococcus in dairy farms, abattoir and humans in Addis Ababa, Ethiopia. BMC Res. Notes 2017, 10, 171. [CrossRef]

91. Wanjala, G.; Mathooko, F.; Kutima, P.; Mathara, J. Microbiological quality and safety of raw and pasteurized milk marketed in and around Nairobi region. Afr. J. Food Agric. Nutr. Dev. 2017, 17, 11518-11532. [CrossRef]

92. Jay, J.M.; Loessner, M.J.; Golden, D.A. Food protection with chemicals, and by biocontrol. Modern Food Microbiol. 2005, 301-350.

93. Giansanti, F.; Panella, G.; Leboffe, L.; Antonini, G. Lactoferrin from milk: Nutraceutical and pharmacological properties. Pharmaceuticals 2016, 9, 61. [CrossRef]

94. Kutila, T.; Pyörälä, S.; Kaartinen, L.; Isomäki, R.; Vahtola, K.; Myllykoski, L.; Saloniemi, H. Lactoferrin and citrate concentrations at drying-off and during early mammary involution of dairy cows. J. Vet. Med. 2003, 50, 350-353. [CrossRef]

95. Van der Strate, B.; Beljaars, L.; Molema, G.; Harmsen, M.; Meijer, D. Antiviral activities of lactoferrin. Antivir. Res. 2001, 52, 225-239. [CrossRef]

96. Barth, C.; Behnke, U. Ernährungsphysiologische Bedeutung von Molke und Molkenbestandteilen. Food/Nahrung 1997, 41, 2-12. [CrossRef] [PubMed]

97. Brown, C.A.; Wang, B.; Oh, J.-H. Antimicrobial activity of lactoferrin against foodborne pathogenic bacteria incorporated into edible chitosan film. J. Food Prot. 2008, 71, 319-324. [CrossRef] [PubMed]

98. Bruni, N.; Capucchio, M.; Biasibetti, E.; Pessione, E.; Cirrincione, S.; Giraudo, L.; Corona, A.; Dosio, F. Antimicrobial activity of lactoferrin-related peptides and applications in human and veterinary medicine. Molecules 2016, 21, 752. [CrossRef] [PubMed]

99. El-Loly, M.M.; Mahfouz, M.B. Lactoferrin in relation to biological functions and applications: A review. Int. J. Dairy Sci. 2011, 6, 79-111. [CrossRef]

100. Levay, P.F.; Viljoen, M. Lactoferrin: A general review. Haematologica 1995, 80, 252-267.

101. Lönnerdal, B.; Iyer, S. Lactoferrin: Molecular structure and biological function. Annu. Rev. Nutr. 1995, 15, 93-110. [CrossRef]

102. Bullen, J.; Rogers, H.J.; Leigh, L. Iron-binding proteins in milk and resistance to Escherichia coli infection in infants. Br. Med. J. 1972, 1, 69-75. [CrossRef]

103. Naidu, A.S.; Arnold, R.R. Influence of lactoferrin on host-microbe interactions. In Lactoferrin; Springer: Berlin, Germany, 1997; pp. 259-275.

104. Zagulski, T.; Jarzabek, Z.; Zagulska, A.; Zimecki, M. The main systemic, highly effective, and quickly acting antimicrobial mechanisms generated by lactoferrin in mammals in vivo. Activity in Health and Disease. In Advances in Lactoferrin Research; Spik, G., Legrand, D., Mazurier, J., Pierce, A., Perraudin, J.P., Eds.; Plenum Press: New York, NY, USA, 1998; pp. 247-250. 
105. Sherman, M.P.; Bennett, S.H.; Hwang, F.F.; Yu, C. Neonatal small bowel epithelia: Enhancing anti-bacterial defense with lactoferrin and Lactobacillus GG. Biometals 2004, 17, 285-289. [CrossRef]

106. Braun, V.; Braun, M. Active transport of iron and siderophore antibiotics. Curr. Opin. Microbiol. 2002, 5, 194-201. [CrossRef]

107. Van Hooijdonk, A.C.; Kussendrager, K.; Steijns, J. In vivo antimicrobial and antiviral activity of components in bovine milk and colostrum involved in non-specific defence. Br. J. Nutr. 2000, 84, 127-134. [CrossRef] [PubMed]

108. Conesa, C.; Rota, C.; Castillo, E.; Perez, M.D.; Calvo, M.; Sanchez, L. Effect of heat treatment on the antibacterial activity of bovine lactoferrin against three foodborne pathogens. Int. J. Dairy Technol. 2010, 63, 209-215. [CrossRef]

109. Korhonen, H.; Marnila, P.; Gill, H. Milk immunoglobulins and complement factors. Br. J. Nutr. 2000, 84, 75-80. [CrossRef] [PubMed]

110. Sánchez, L.; Peiro, J.; Castillo, H.; Perez, M.; Ena, J.; Calvo, M. Kinetic parameters for denaturation of bovine milk lactoferrin. J. Food Sci. 1992, 57, 873-879. [CrossRef]

111. Koksal, Z.; Gulcin, I.; Ozdemir, H. An Important Milk Enzyme: Lactoperoxidase. Milk Proteins 2016, 141.

112. Sarikaya, S.B.O.; Sisecioglu, M.; Cankaya, M.; Gulcin, İ.; Ozdemir, H. Inhibition profile of a series of phenolic acids on bovine lactoperoxidase enzyme. J. Enzyme Inhib. Med. Chem. 2015, 30, 479-483. [CrossRef]

113. Sarr, D.; Tóth, E.; Gingerich, A.; Rada, B. Antimicrobial actions of dual oxidases and lactoperoxidase. J. Microbiol. 2018, 56, 373-386. [CrossRef]

114. Cheng, R.; Mantovani, A.; Frazzoli, C. Analysis of food safety and security challenges in emerging African food producing areas through a One Health lens: The dairy chains in Mali. J. Food Prot. 2016, 80, 57-67. [CrossRef]

115. FAO/WHO. Benefits and Potential Risks of the Lactoperoxidase System of Raw Milk Preservation; Report of an FAO/WHO Technical Meeting FAO Headquarters, Rome, Italy, from 28 November-2 December, 2005; FAO/WHO: Rome, Italy, 2006; pp. 5-17.

116. Cosentino, C.; Labella, C.; Elshafie, H.; Camele, I.; Musto, M.; Paolino, R.; D’adamo, C.; Freschi, P. Effects of different heat treatments on lysozyme quantity and antimicrobial activity of jenny milk. J. Dairy Sci. 2016, 99, 5173-5179. [CrossRef]

117. Fox, P.; Kelly, A. Indigenous enzymes in milk: Overview and historical aspects-Part 1. Int. Dairy J. 2006, 16, 500-516. [CrossRef]

118. Silanikove, N.; Merin, U.; Leitner, G. Physiological role of indigenous milk enzymes: An overview of an evolving picture. Int. Dairy J. 2006, 16, 533-545. [CrossRef]

119. Losnedahl, K.J.; Wang, H.; Aslam, M.; Zou, S.; Hurley, W.L. Antimicrobial factors in milk. Illini DairyNet Papers 1998, 38, 1-4.

120. Sudagidan, M.; Yemenicioğlu, A. Effects of nisin and lysozyme on growth inhibition and biofilm formation capacity of Staphylococcus aureus strains isolated from raw milk and cheese samples. J. Food Prot. 2012, 75, 1627-1633. [CrossRef] [PubMed]

121. Agyei, D.; Owusu-Kwarteng, J.; Akabanda, F.; Akomea-Frempong, S. Indigenous African fermented dairy products: Processing technology, microbiology and health benefits. Crit. Rev. Food Sci. Nutr. 2019, 1-16. [CrossRef]

122. Akabanda, F.; Owusu-Kwarteng, J.; Tano-Debrah, K.; Glover, R.L.; Nielsen, D.S.; Jespersen, L. Taxonomic and molecular characterization of lactic acid bacteria and yeasts in nunu, a Ghanaian fermented milk product. Food Microbiol. 2013, 34, 277-283. [CrossRef]

123. Benkerroum, N. Traditional fermented foods of North African countries: Technology and food safety challenges with regard to microbiological risks. Compr. Rev. Food Sci. 2013, 12, 54-89. [CrossRef]

124. WHO/FAO. Risk Assessment of Listeria Monocytogenes in Ready-To-Eat Foods: Technical Report, Microbiological Risk Assessment; FAO Report, Series No. 5; FAO: Rome, Italy, 2004; pp. 1-307.

125. Claeys, W.L.; Cardoen, S.; Daube, G.; De Block, J.; Dewettinck, K.; Dierick, K.; De Zutter, L.; Huyghebaert, A.; Imberechts, H.; Thiange, P. Raw or heated cow milk consumption: Review of risks and benefits. Food Control. 2013, 31, 251-262. [CrossRef]

126. Farrokh, C.; Jordan, K.; Auvray, F.; Glass, K.; Oppegaard, H.; Raynaud, S.; Thevenot, D.; Condron, R.; De Reu, K.; Govaris, A. Review of Shiga-toxin-producing Escherichia coli (STEC) and their significance in dairy production. Int. J. Food Microbiol. 2013, 162, 190-212. [CrossRef] 
127. Obodai, M.; Dodd, C. Characterization of dominant microbiota of a Ghanaian fermented milk product, nyarmie, by culture-and nonculture-based methods. J. Appl. Microbiol. 2006, 100, 1355-1363. [CrossRef]

128. Nieminen, M.T.; Novak-Frazer, L.; Collins, R.; Dawsey, S.P.; Dawsey, S.M.; Abnet, C.C.; White, R.E.; Freedman, N.D.; Mwachiro, M.; Bowyer, P. Alcohol and acetaldehyde in African fermented milk mursik-A possible etiologic factor for high incidence of esophageal cancer in western Kenya. Cancer Epidemiol. Biomark. Prev. 2013, 22, 69-75. [CrossRef]

129. Nyambane, B.; Thari, W.M.; Wangoh, J.; Njage, P.M. Lactic acid bacteria and yeasts involved in the fermentation of amabere amaruranu, a Kenyan fermented milk. Food Sci. Nutr. 2014, 2, 692-699. [CrossRef] [PubMed]

130. Schutte, L.M. Isolation and Identification of the Microbial Consortium Present in Fermented Milks from Sub-Saharan Africa. Master's Thesis, Stellenbosch University, Stellenbosch, South Africa, 2013; pp. 96-118.

131. Jiwoua, C.; Milliere, J. Lactic flora and enterococci of fermented [zebu] milk (pindidam) produced in Adamaoua (Cameroun). Lait (France) 1990, 70, 475-486. [CrossRef]

132. Mbawala, A.; Mahbou, P.; Mouafo, H.; Tatsadjieu, L. Antibacterial activity of some lactic acid bacteria isolated from a local fermented milk product (pendidam) in Ngaoundere, Cameroon. J. Anim. Plant. Sci. 2013, 23, 157-166.

133. Belli, P.; Cantafora, A.F.; Stella, S.; Barbieri, S.; Crimella, C. Microbiological survey of milk and dairy products from a small scale dairy processing unit in Maroua (Cameroon). Food Control. 2013, 32, 366-370. [CrossRef]

134. Feresu, S.B.; Muzondo, M. Identification of some lactic acid bacteria from two Zimbabwean fermented milk products. World J. Microbiol. Biotechnol. 1990, 6, 178-186. [CrossRef]

135. Jans, C.; Meile, L.; Kaindi, D.W.M.; Kogi-Makau, W.; Lamuka, P.; Renault, P.; Kreikemeyer, B.; Lacroix, C.; Hattendorf, J.; Zinsstag, J. African fermented dairy products-overview of predominant technologically important microorganisms focusing on African Streptococcus infantarius variants and potential future applications for enhanced food safety and security. Int. J. Food Microbiol. 2017, 250, 27-36. [CrossRef]

136. Mathara, J.M.; Schillinger, U.; Kutima, P.M.; Mbugua, S.K.; Holzapfel, W.H. Isolation, identification and characterisation of the dominant microorganisms of kule naoto: The Maasai traditional fermented milk in Kenya. Int. J. Food Microbiol. 2004, 94, 269-278. [CrossRef]

137. Savadogo, A.; Ouattara, C.; Savadogo, P.; Ouattara, A.; Barro, N.; Traore, A. Microorganisms involved in Fulani traditional fermented milk in Burkina Faso. Pak. J. Nutr. 2004, 3, 134-139.

138. Daeschel, M.A. Applications and interactions of bacteriocins from lactic acid bacteria in foods and beverages. In Bacteriocins of Lactic Acid Bacteria; Hoover, D.G., Steenson, L.R., Eds.; Elsevier: New York, NY, USA, 1993; pp. 63-91.

139. Tejero-Sariñena, S.; Barlow, J.; Costabile, A.; Gibson, G.R.; Rowland, I. In vitro evaluation of the antimicrobial activity of a range of probiotics against pathogens: Evidence for the effects of organic acids. Anaerobe 2012, 18, 530-538. [CrossRef]

140. Wakil, S.; Osamwonyi, U. Isolation and screening of antimicrobial producing lactic acid bacteria from fermenting millet gruel. Int. Res. J. Microbiol. 2012, 3, 072-079.

141. Byczkowski, J.Z.; Gessner, T. Biological role of superoxide ion-radical. Int. J. Biochem. 1988, 20, 569-580. [CrossRef]

142. Kong, S.; Davison, A.J. The role of interactions between $\mathrm{O}_{2}, \mathrm{H}_{2} \mathrm{O}_{2}, \mathrm{OH}$, e- and $\mathrm{O} 2-$ in free radical damage to biological systems. Arch. Biochem. Biophys. 1980, 204, 18-29. [CrossRef]

143. Ricke, S. Perspectives on the use of organic acids and short chain fatty acids as antimicrobials. Poultr. Sci. 2003, 82, 632-639. [CrossRef] [PubMed]

144. Akabanda, F.; Owusu-Kwarteng, J.; Tano-Debrah, K.; Parkouda, C.; Jespersen, L. The use of lactic acid bacteria starter culture in the production of Nunu, a spontaneously fermented milk product in Ghana. Int. J. Food Sci. 2014, 2014.

145. Akabanda, F.; Owusu-Kwarteng, J.; Glover, R.; Tano-Debrah, K. Microbiological characteristics of Ghanaian traditional fermented milk product, Nunu. Nat. Sci. 2010, 8, 178-187.

146. Cotter, P.D.; Hill, C.; Ross, R.P. Food microbiology: Bacteriocins: Developing innate immunity for food. Nat. Rev. Microbiol. 2005, 3, 777. [CrossRef]

147. Stevens, K.; Sheldon, B.; Klapes, N.A.; Klaenhammer, T. Nisin treatment for inactivation of Salmonella species and other gram-negative bacteria. Appl. Environ. Microbiol. 1991, 57, 3613-3615. [CrossRef] 
148. de Arauz, L.J.; Jozala, A.F.; Mazzola, P.G.; Penna, T.C.V. Nisin biotechnological production and application: A review. Trends Food Sci. Technol. 2009, 20, 146-154. [CrossRef]

149. Ávila, M.; Gómez-Torres, N.; Hernández, M.; Garde, S. Inhibitory activity of reuterin, nisin, lysozyme and nitrite against vegetative cells and spores of dairy-related Clostridium species. Int. J. Food Microbiol. 2014, 172, 70-75. [CrossRef]

150. Rodríguez, E.; González, B.; Gaya, P.; Nuñez, M.; Medina, M. Diversity of bacteriocins produced by lactic acid bacteria isolated from raw milk. Int. Dairy J. 2000, 10, 7-15. [CrossRef]

151. Leroy, F.; De Vuyst, L. Lactic acid bacteria as functional starter cultures for the food fermentation industry. Trends Food Sci. Technol. 2004, 15, 67-78. [CrossRef]

152. Patrovský, M.; Kouřimská, L.; Havlíková, Š.; Marková, J.; Pechar, R.; Rada, V. Utilization of bacteriocin-producing bacteria in dairy products. Mljekarstvo: Časopis za unaprjeđenje proizvodnje i prerade mlijeka 2016, 66, 215-224. [CrossRef]

153. García, P.; Martínez, B.; Rodríguez, L.; Rodríguez, A. Synergy between the phage endolysin LysH5 and nisin to kill Staphylococcus aureus in pasteurized milk. Int. J. Food Microbiol. 2010, 141, 151-155. [CrossRef] [PubMed]

154. Sánchez-Hidalgo, M.; Montalbán-López, M.; Cebrián, R.; Valdivia, E.; Martínez-Bueno, M.; Maqueda, M. AS-48 bacteriocin: Close to perfection. Cell. Mol. Life Sci. 2011, 68, 2845-2857.

155. Suda, S.; D Cotter, P.; Hill, C.; Paul Ross, R. Lacticin 3147-biosynthesis, molecular analysis, immunity, bioengineering and applications. Curr. Protein Pept. Sci. 2012, 13, 193-204. [CrossRef]

156. Aunsbjerg, S.D.; Honoré, A.H.; Marcussen, J.; Ebrahimi, P.; Vogensen, F.K.; Benfeldt, C.; Skov, T.; Knøchel, S. Contribution of volatiles to the antifungal effect of Lactobacillus paracasei in defined medium and yogurt. Int. J. Food Microbiol. 2015, 194, 46-53. [CrossRef]

157. Delavenne, E.; Ismail, R.; Pawtowski, A.; Mounier, J.; Barbier, G.; Le Blay, G. Assessment of lactobacilli strains as yogurt bioprotective cultures. Food Control. 2013, 30, 206-213. [CrossRef]

158. Lačanin, I.; Mounier, J.; Pawtowski, A.; Dušková, M.; Kameník, J.; Karpíšková, R. Assessment of the antifungal activity of Lactobacillus and Pediococcus spp. for use as bioprotective cultures in dairy products. World J. Microbiol. Biotechnol. 2017, 33, 188. [CrossRef]

159. Cheong, E.Y.; Sandhu, A.; Jayabalan, J.; Le, T.T.K.; Nhiep, N.T.; Ho, H.T.M.; Zwielehner, J.; Bansal, N.; Turner, M.S. Isolation of lactic acid bacteria with antifungal activity against the common cheese spoilage mould Penicillium commune and their potential as biopreservatives in cheese. Food Control. 2014, 46, 91-97. [CrossRef]

160. Hassanin, N.I. Stability of aflatoxin M1 during manufacture and storage of yoghurt, yoghurt-cheese and acidified milk. J. Sci. Food Agric. 1994, 65, 31-34. [CrossRef]

161. Motawee, M. Reduction of aflatoxin M1 content during manufacture and storage of Egyptian Domaiti Cheese. Int J. Vet. Med. Res. Rep. 2013, 2013, 1-11. [CrossRef]

162. Bianchini, A.; Bullerman, L.B. Biological Control of Molds and Mycotoxins in Foods; ACS Publications: Washington, DC, USA, 2009; pp. 1-16.

163. Ahlberg, S.H.; Joutsjoki, V.; Korhonen, H.J. Potential of lactic acid bacteria in aflatoxin risk mitigation. Int. J. Food Microbiol. 2015, 207, 87-102. [CrossRef] [PubMed]

164. Blagojev, N.; Škrinjar, M.; Vesković-Moračanin, S.; Šošo, V. Control of mould growth and mycotoxin production by lactic acid bacteria metabolites. Rom. Biotechnol. Lett. 2012, 17, 7219-7226.

165. Mathara, J.M. Studies on Lactic Acid Producing Microflora in Mursik and Kule Naoto, Traditional Fermented Milks from Nandi and Masai Communities in Kenya. In Master's Thesis; University of Nairobi: Nairobi, Kenya, 1999.

166. Onyango, C.; Gakuya, L.; Mathooko, F.M.; Maina, J.; Nyaberi, M.; Makobe, M.; Mwaura, F. Preservative effect of various indigenous plants on fermented milk from Maasai community of Kajiado County. J. Appl. Biosci. 2014, 73, 5935-5941.

167. Mathara, J.; Miyamoto, T.; Koaze, H. Production of Traditional Fermented Milk in Kenya (A Review); Shizuoka Prefectural University Publication: Shizuoka, Japan, 1995; pp. 257-264.

168. Nduko, J.M.; Matofari, J.W.; Nandi, Z.O.; Sichangi, M.B. Spontaneously fermented Kenyan milk products: A review of the current state and future perspectives. Afr. J. Food Sci. 2017, 11, 1-11.

169. Cabarello, B.; Trugo, L.; Finglas, P. Encyclopedia of Food Science and Nutrition, 2nd ed.; Elsevier Academic Press: Amsterdam, The Netherlands, 2003. 
170. Laranjo, M.; Elias, M.; Fraqueza, M.J. The use of starter cultures in traditional meat products. J. Food Qual. 2017, 2017. [CrossRef]

171. Wouters, D.; Grosu-Tudor, S.; Zamfir, M.; De Vuyst, L. Applicability of Lactobacillus plantarum IMDO 788 as a starter culture to control vegetable fermentations. J. Sci. Food Agric. 2013, 93, 3352-3361. [CrossRef]

172. Cogan, T.; Beresford, T.; Steele, J.; Broadbent, J.; Shah, N.; Ustunol, Z. Invited review: Advances in starter cultures and cultured foods. J. Dairy Sci. 2007, 90, 4005-4021. [CrossRef]

173. Parente, E.; Cogan, Y.M.; Powell, I.B. Starter Cultures: General Aspects. In Cheese: Chemistry, Physics and Microbiology, 4th ed.; McSweeney, P.L.H., Fox, P.F., Cotter, P.D., Everett, D.W., Eds.; Elsevier Academic Press: Oxford, UK, 2017; Volume 1, pp. 201-226.

174. Ross, T.; McMeekin, T. Predictive microbiology. Int. J. Food Microbiol 1994, 23, 241-264. [CrossRef]

175. Valdramidis, V. Predictive microbiology. In Modeling in Food Microbiology; Valdramidis, J.-M.M.V., Ed.; Elsevier: Oxford, UK, 2016.

176. Devasundaram, J.; Cariappa, A. Problems of erratic power supply in Africa and India. Leprosy Rev. 1987, 58, 431-432.

177. Ibrahim, A.; Aryeetey, G.C.; Asampong, E.; Dwomoh, D.; Nonvignon, J. Erratic electricity supply (Dumsor) and anxiety disorders among university students in Ghana: A cross sectional study. Int. J. Ment. Health Syst. 2016, 10, 17. [CrossRef] [PubMed]

178. Verploegen, E.; Rinker, P.; Ognakossan, K.E. Evaporative Cooling Best Practices: Producing and Using Evaporative Cooling Chambers and Clay Pot Coolers; MIT D-Lab: Cambridge, UK, 2018; pp. 1-31.

(C) 2020 by the authors. Licensee MDPI, Basel, Switzerland. This article is an open access article distributed under the terms and conditions of the Creative Commons Attribution (CC BY) license (http://creativecommons.org/licenses/by/4.0/). 